\title{
Modelling global-scale climate impacts of the late Miocene Messinian Salinity Crisis
}

\author{
R. F. Ivanovic ${ }^{1,2}$, P. J. Valdes ${ }^{2}$, R. Flecker ${ }^{2}$, and M. Gutjahr ${ }^{3}$ \\ ${ }^{1}$ School of Earth \& Environment, University of Leeds, Leeds, UK \\ ${ }^{2}$ School of Geographical Sciences, University of Bristol, Bristol, UK \\ ${ }^{3}$ GEOMAR Helmholtz Centre for Ocean Research Kiel, Kiel, Germany \\ Correspondence to: R. F. Ivanovic (r.ivanovic@leeds.ac.uk) \\ Received: 16 July 2013 - Published in Clim. Past Discuss.: 20 August 2013 \\ Revised: 29 January 2014 - Accepted: 11 February 2014 - Published: 25 March 2014
}

\begin{abstract}
Late Miocene tectonic changes in MediterraneanAtlantic connectivity and climatic changes caused Mediterranean salinity to fluctuate dramatically, including a tenfold increase and near-freshening. Recent proxy- and modelbased evidence suggests that at times during this Messinian Salinity Crisis (MSC, 5.96-5.33 Ma), highly saline and highly fresh Mediterranean water flowed into the North Atlantic Ocean, whilst at others, no Mediterranean Outflow Water (MOW) reached the Atlantic. By running extreme, sensitivity-type experiments with a fully coupled oceanatmosphere general circulation model, we investigate the potential of these various MSC MOW scenarios to impact global-scale climate.

The simulations suggest that although the effect remains relatively small, MOW had a greater influence on North Atlantic Ocean circulation and climate than it does today. We also find that depending on the presence, strength and salinity of MOW, the MSC could have been capable of cooling mid-high northern latitudes by a few degrees, with the greatest cooling taking place in the Labrador, Greenland-IcelandNorwegian and Barents seas. With hypersaline MOW, a component of North Atlantic Deep Water formation shifts to the Mediterranean, strengthening the Atlantic Meridional Overturning Circulation (AMOC) south of $35^{\circ} \mathrm{N}$ by $1.5-6 \mathrm{~Sv}$. With hyposaline MOW, AMOC completely shuts down, inducing a bipolar climate anomaly with strong cooling in the north (mainly -1 to $-3^{\circ} \mathrm{C}$, but up to $-8^{\circ} \mathrm{C}$ ) and weaker warming in the south (up to +0.5 to $+2.7^{\circ} \mathrm{C}$ ).

These simulations identify key target regions and climate variables for future proxy reconstructions to provide the best and most robust test cases for (a) assessing Messinian model
\end{abstract}

performance, (b) evaluating Mediterranean-Atlantic connectivity during the MSC and (c) establishing whether or not the MSC could ever have affected global-scale climate.

\section{Introduction}

During the latest Miocene (the Messinian) a series of dramatic, basin-wide salinity fluctuations affected the Mediterranean (Fig. 1). These are thought to have been caused by progressive tectonic restriction of the MediterraneanAtlantic seaways (e.g. Hsu et al., 1977; Krijgsman et al., 1999a). This event, the Messinian Salinity Crisis (MSC), is recorded in a sequence comprising thick gypsum and halite evaporites (Fig. 1), which indicate a three- to tenfold increase in Mediterranean salinity above present-day conditions (e.g. Decima and Wezel, 1973; Krijgsman et al., 1999a), and ostracod-rich Lago Mare facies, which suggest that at times, Mediterranean salinity declined to brackish or near-fresh conditions (Decima and Wezel, 1973).

The effect that the MSC may have had on globalscale climate has yet to be fully explored. Murphy et al. (2009) and Schneck et al. (2010) investigated the impact of Mediterranean Sea level change, as well as total evaporation and revegetation of the Mediterranean basin, using an atmosphere-only General Circulation Model (GCM) and Earth system model of intermediate complexity, respectively. They found a generally localised impact (for example, $7^{\circ} \mathrm{C}$ annual mean warming, $\pm 600 \mathrm{~mm} \mathrm{yr}^{-1}$ of precipitation, mostly in good agreement with the fossil record; Griffin, 1999), mainly affecting the Alps and Northern Africa, but 


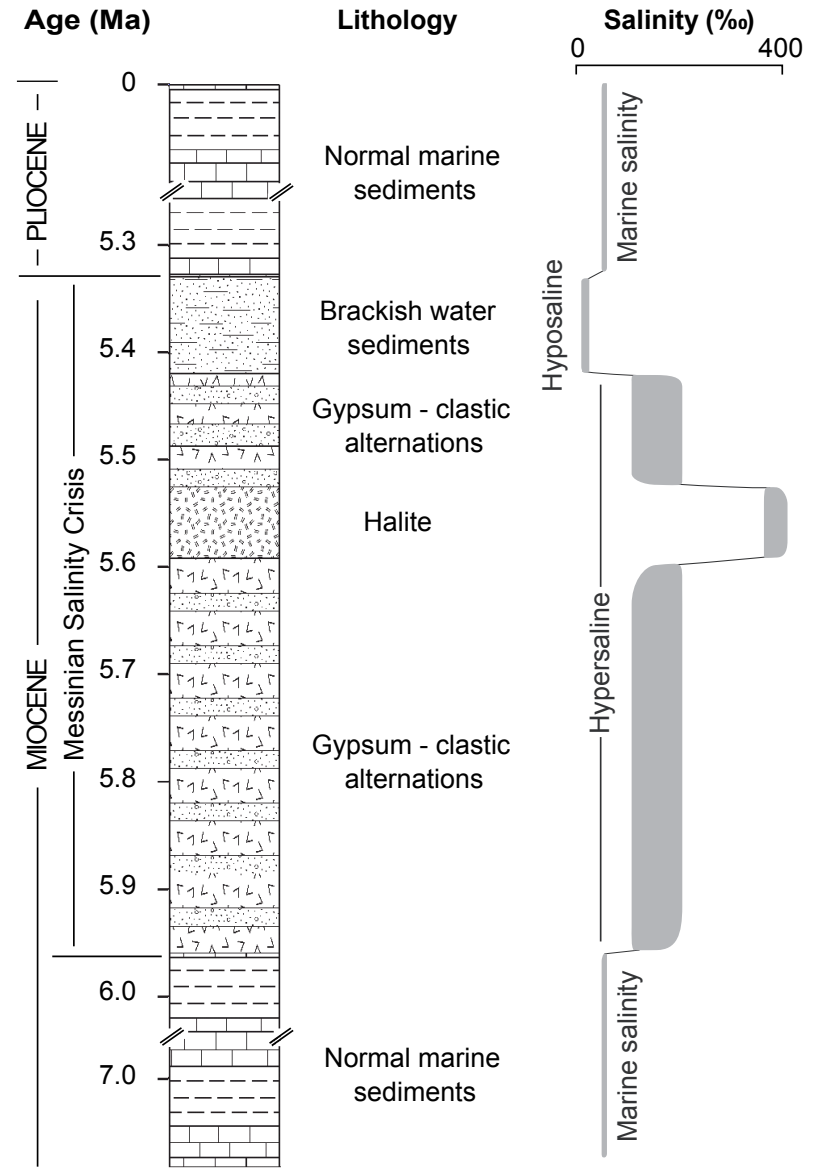

Fig. 1. Schematic composite section of the main Mediterranean lithologies over the Messinian Salinity Crisis, including the corresponding salinities in which the successions were deposited/precipitated (after Ivanovic et al., 2013a). Timing of event boundaries are after Roveri et al. (2008) and references therein.

with some influence (cooling) over the high-latitude oceans (North Atlantic, North Pacific and the Gulf of Alaska; Murphy et al., 2009). Others have considered the influence of Mediterranean Outflow Water (MOW) on present-day and Quaternary global-scale climate through its ability to modify North Atlantic circulation (Bigg and Wadley, 2001; Chan and Motoi, 2003; Ivanovic et al., 2014; Kahana, 2005; Rahmstorf, 1998; Rogerson et al., 2010). However, none have investigated the impact of MSC changes in MOW on ocean circulation and climate.

It has been widely postulated that there was no Mediterranean outflow during episodes of Mediterranean hypersalinity and this must have been true if the Mediterranean fully desiccated during halite precipitation (e.g. Hsu et al., 1973; Ryan and Cita, 1978). However, the evidence for complete desiccation remains controversial (e.g. Canals et al., 2006; Roveri et al., 2011) and alternative hypotheses have been put forward invoking a less substantial Mediterranean sea level fall and even sustained MOW during periods of Mediter- ranean hypersalinity (e.g. Flecker and Ellam, 2006; Fortuin and Krijgsman, 2003; Krijgsman and Meijer, 2008; Lugli et al., 2010; Meijer, 2012; Topper et al., 2011). In addition, it is difficult to envisage how enough salt could have been brought into the Mediterranean to explain the $1-3 \mathrm{~km}$-thick Messinian evaporite sequence visible in the seismic record (Lofi et al., 2011; Ryan et al., 1973) without inflow from the Atlantic.

From box modelling and hydrologic budget calculations, total desiccation of the Mediterranean is estimated to have taken 1-10 kyr (Benson et al., 1991; Blanc, 2000; Hsu et al., 1973; Meijer and Krijgsman, 2005; Topper et al., 2011), producing a layer of evaporite that is $24-47 \mathrm{~m}$ thick in the process (Meijer and Krijgsman, 2005). This is less than $2 \%$ of the total volume of evaporite thought to have precipitated out of solution around $500 \mathrm{ka}$ (Krijgsman et al., 1999a) or less (Garcia-Castellanos and Villaseñor, 2011) during the Messinian. Thus, one desiccation-reflooding cycle would be required approximately every $6-7 \mathrm{ka}$. The solar precession mechanism put forward to explain the observed cyclicity in Messinian Mediterranean sediments has a periodicity of $21 \mathrm{kyr}$ (Krijgsman et al., 1999a), too long to reconcile the desiccation hypothesis with the volume of evaporites precipitated. Other hypotheses encompass cycles of $10 \mathrm{kyr}$ or less (Garcia-Castellanos and Villaseñor, 2011).

A more likely scenario, consistent with both model results (e.g. Gladstone et al., 2007; Meijer and Krijgsman, 2005; Meijer, 2006, 2012) and data (Abouchami et al., 1999; Ivanovic et al., 2013a; Muiños et al., 2008) is that the Mediterranean was often connected to the Atlantic during MSC hyper- and hypo-salinity, particularly during episodes of gypsum formation and near-freshening, with at least periodic Mediterranean outflow to the Atlantic.

It is the purpose of this modelling study to investigate both the impact of hyper- and hypo-saline MOW on global-scale Messinian climate and to evaluate the consequences of no Mediterranean water reaching the Atlantic. From this work, it is possible to determine the climate variables and geographical regions that are most susceptible to MSC-influenced climate changes. To this end, we here present a series of fully coupled atmosphere-ocean GCM simulations, which assess Messinian climate sensitivity to extreme end-member changes in MOW that may have occurred during the MSC. In the absence of data to confirm whether or not MOW underwent dramatic fluctuations in salinity in the late Miocene, we ask the question of whether the MSC could ever have affected global-scale climate in the most extreme, geologically constrained, Mediterranean salinity scenarios. 


\section{Methods}

\subsection{Model description}

The climate simulations for this study were run with the UK Met Office's fully coupled atmosphere-ocean GCM HadCM3, version 4.5. The atmosphere model has a horizontal resolution of $2.5^{\circ} \times 3.75^{\circ}$, 19 vertical layers (using the hybrid vertical coordinate scheme of Simmons and Burridge, 1981) and a time step of $30 \mathrm{~min}$. It includes physical parameterisations for the radiation scheme (as per Edwards and Slingo, 1996), convection scheme (as per Gregory et al., 1997) and land surface scheme (MOSES-1; Cox et al., 1999). This particular version of HadCM3 does not include a dynamic vegetation model; the vegetation distribution for each simulation is prescribed and remains fixed.

The ocean model is more finely resolved, with a $1.25^{\circ} \times 1.25^{\circ}$ horizontal grid and 20 vertical levels that have been designed to give maximum resolution towards the ocean surface (Johns et al., 1997). It has a fixed lid, which means that the ocean grid boxes (and hence sea level) cannot vary. Consequently, evaporation, precipitation and river runoff are represented as a salt flux (Gordon et al., 2000). Included in the ocean model's physical parameterisations are an eddymixing scheme (Visbeck et al., 1997), an isopycnal diffusion scheme (Gent and Mcwilliams, 1990) and a simple thermodynamic sea-ice scheme of ice drift and leads (Cattle et al., 1995) and ice concentration (Hibler, 1979). Gordon et al. (2000) show that HadCM3 reproduces modern sea surface temperatures well without needing to apply unphysical "flux adjustments" at the ocean-atmosphere interface.

The ocean equation of state is based on Bryan and Cox (1972) and is an approximation to the Knudsen formula (Fofonoff, 1962). Although this is a relatively old version, the percentage deviation from the UNESCO standards (Fofonoff and Millard, 1983) is small for salinities in the normal range (0-42 psu). At very high salinity values, none of the existing equations of state are valid. However, the density of sea water predicted from our approximation was within $1 \%$ of those shown in Dvorkin et al. (2007) for the Dead Sea (at depth $=0$ and temperature $=25^{\circ} \mathrm{C}$ ). Moreover, we are not attempting to predict the flow within the Mediterranean itself. Instead we are examining the effect of the outflow on the global climate system, and mixing close to the straights rapidly brings the hypersaline flow to within the validity bounds of the equation of state.

The ocean and atmosphere components are coupled once per model day. To account for the different grid resolutions, the ocean grid is aligned with the atmosphere grid and thus the constituent models pass across the fluxes accumulated over the previous 24 model hours by interpolating and averaging across the grids as appropriate. Rivers are discharged to the ocean by the instantaneous delivery of continental runoff (from precipitation) to the coasts, according to griddefined river catchments and estuaries. Gordon et al. (2000)

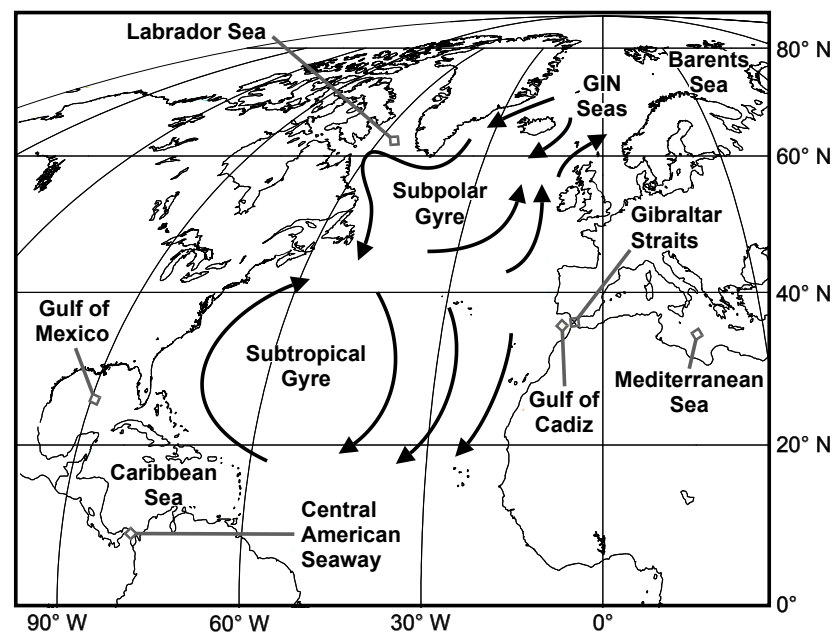

Fig. 2. Map of the North Atlantic region marked with key geographical areas discussed in the text. Schematic representations of the modern North Atlantic subtropical and subpolar ocean gyre circulations are also shown.

and Pope et al. (2000) give a more detailed description of the model and its components, including improvements on earlier versions.

With a new generation of high-resolution GCMs, HadCM3 may no longer be considered "state of the art". However, its relatively fast model speed (compared to more recent versions) enables long integrations of several centuries to be made. This is necessary for ocean circulation to approach near-steady state in our simulations, so that the surface climates and large-scale ocean circulations and heat/salt transports, including Atlantic Meridional Ocean Circulation (AMOC), are in an equilibrium state in the model (Ivanovic et al., 2014). Also, previous studies suggest that it is important to run the model for at least several centuries to capture the effect of changes in MOW on North Atlantic circulation and climate (Bigg and Wadley, 2001; Chan and Motoi, 2003; Kahana, 2005).

\subsection{Mediterranean-Atlantic exchange}

Neither the Gibraltar straits (location indicated by Fig. 2), nor the late Miocene Mediterranean-Atlantic seaways (e.g. Betzler et al., 2006; Duggen et al., 2003; Martín et al., 2009; Santisteban and Taberner, 1983) can be resolved on the HadCM3 grid. Instead, a parameterisation of Mediterranean-Atlantic water exchange is employed for modern flow through the Gibraltar straits, which partially mixes thermal and saline properties between the two basins based on temperature and salinity gradients and according to a constant coefficient of exchange $(\mu)$. As such, $\mu$ also represents the control of Mediterranean-Atlantic gateway geometry on the exchange. We have used the same parameterisation for the late Miocene simulations carried out in this study. Thus, the net heat and 
salt flux is calculated for two corresponding pairs of grid boxes, either side of the land bridge linking the European and African continents (marked by the red crosses in Fig. 3). This is carried out in the upper 13 ocean levels of the model, 0 to $1 \mathrm{~km}$ depth, which is an appropriate palaeobathymetry in the model for either side of the Messinian MediterraneanAtlantic seaways (e.g. van Assen et al., 2006; Fortuin and Krijgsman, 2003; Hilgen et al., 2000; Hodell et al., 1994; Krijgsman, 2001; Krijgsman et al., 2004; van der Laan et al., 2006). Although the continental seaways were probably not this deep, or at least not for the entire Messinian, because of the model's horizontal resolution constraints, the parameterisation also necessarily captures part of the mixing and flow that occurs above the continental shelf in the Gulf of Cadiz (Atlantic) and the Alboran Sea (Mediterranean). If the pipe was shallower than this, flow through the marine gateways would reach too far into the Atlantic and Mediterranean basins at too shallow depth, and insufficient mixing between Mediterranean and Atlantic waters would take place in proximity to the straits. It is because of these model resolution limitations that a seemingly over-deep pipe is used to represent exchange through the seaway (similar to Ivanovic et al., 2014). Thus, for every level and at every time step, the mean of the four points is calculated for each tracer field $(\bar{T})$. Then, where $T_{j}$ is the tracer for each of the four grid boxes, the difference between the old (previous time step) and the new (current time step) tracer is given as

$$
\left.\frac{\partial T_{j}}{\partial t}\right|_{\text {pipe }}=\mu\left(T_{j}-\bar{T}\right)
$$

(Gordon et al., 2000), where $\mu$ is a given coefficient of Mediterranean-Atlantic exchange and $\left.\frac{\partial T_{j}}{\partial t}\right|_{\text {pipe }}$ is the tracer tendency for the pipe parameterisation.

This parameterisation (described in more detail by Ivanovic et al., 2014) achieves $\sim 1 \mathrm{~Sv}$ of easterly and westerly "flow" through the Gibraltar straits for the present day, which is close to contemporary observational values ( $>0.74 \pm 0.05 \mathrm{~Sv}$; García-Lafuente et al., 2011). The model successfully simulates the two-layer flow structure observed for present-day exchange through the straits (e.g. Bethoux and Gentili, 1999), with a surface eastward flow of North Atlantic Central Water (NACW) into the Mediterranean and a deeper westward flow of MOW into the Atlantic. Due to net evaporation over the Mediterranean, MOW is up to 2 psu saltier than the NACW it flows into (note that this difference is smaller than the difference in salinity between the westernmost Mediterranean and easternmost Atlantic due to mixing of the water masses in the exchange).

An important caveat to consider for this study is that the model is not fine-scaled enough to fully resolve the complex flow structure of MOW and Atlantic inflow water in what is now the Gibraltar Strait-Gulf of Cadiz region (location indicated by Fig. 2). Consequently, Mediterranean eddies (meddies) and processes of North Atlantic entrainment in

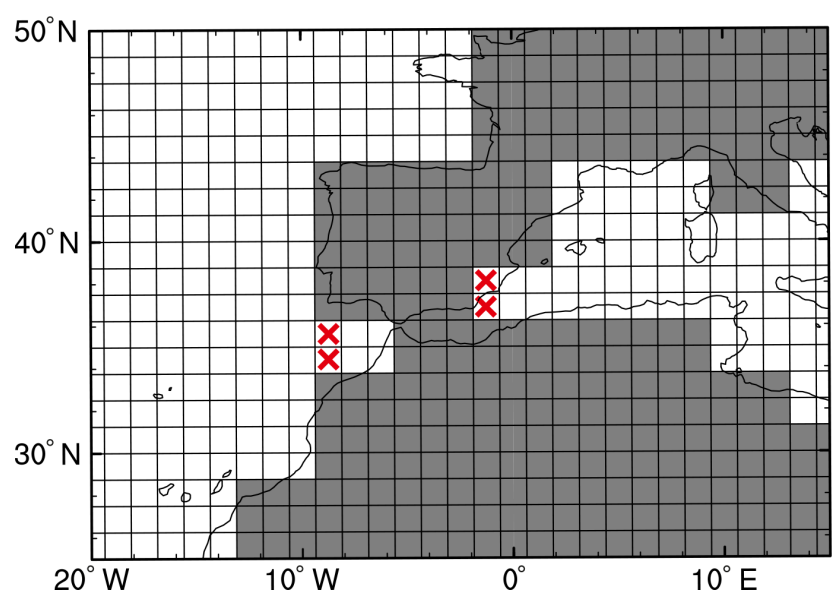

Fig. 3. HadCM3 land-sea mask in the Gibraltar straits region, with the model's ocean grid and modern coastline overlain. Land is in grey, ocean in white. The four red crosses mark the grid boxes either side of the European-African land bridge that are connected by the "pipe" parameterisation of Mediterranean-Atlantic water exchange (see text in Sect. 2.2).

MOW are not directly simulated. Meddies are partially represented by $\mu$ in the Mediterranean-Atlantic exchange parameterisation, although overall, HadCM3 probably underestimates shallow-intermediate mixing of MOW with ambient NACW (Ivanovic et al., 2013b). North Atlantic entrainment, on the other hand, is represented by diffusive mixing of MOW with Atlantic water as it descends the continental shelf and spreads westwards. It is likely overestimated in HadCM3, because the model's depth-based $(z)$ coordinate system (Johns et al., 1997, Table 2) incompletely resolves the dense, bottom-hugging overflow of MOW into the Atlantic (e.g. Griffies et al., 2000). These two effects partly counteract each other, resulting in the fairly good reproduction of the large-scale features of MOW in the North Atlantic today (e.g. as seen in Boyer et al., 2009). However, this also makes it difficult to interpret their individual impact on model sensitivity to changes in MOW buoyancy.

\subsection{Experiment design}

\subsubsection{Messinian control configuration}

The MSC took place at the end of the Miocene (5.96$5.33 \mathrm{Ma}$ ) and hence falls between the sub-epochs of the late Miocene (mid-point $\sim 8 \mathrm{Ma}$ ) and early Pliocene (mid-point $\sim 4.5 \mathrm{Ma}$ ). Key palaeogeographic characteristics of this period (Markwick, 2007) include lowered topography in the Americas and Himalayas, a reduced Greenland ice cap and an open Central American Seaway (CAS, location indicated by Fig. 2).

Compared to the modern set-up, the palaeo-configuration for the Messinian HadCM3 simulation (subsequently referred to as Messinian control) consists of raising global 

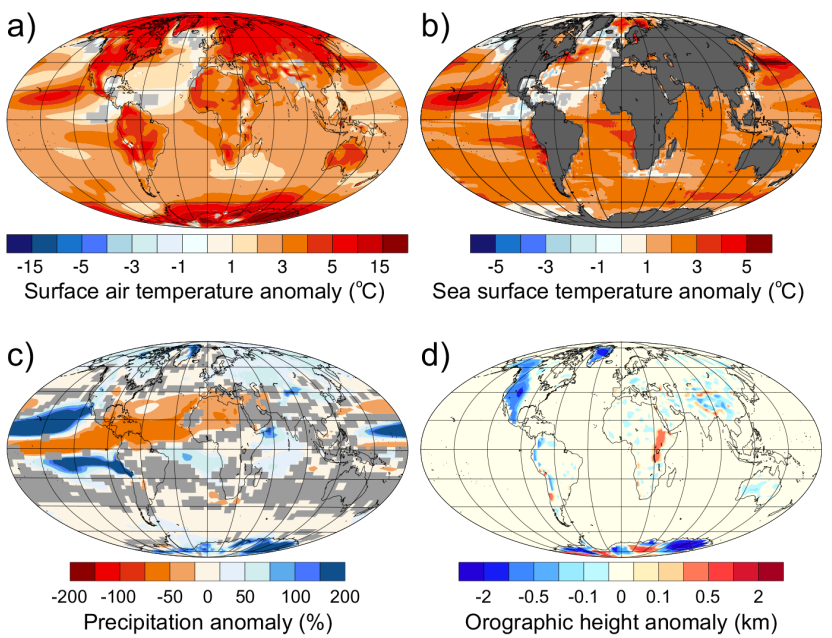

Fig. 4. Annual mean difference between the Messinian control versus the modern (pre-industrial) control simulation (as used by Ivanovic et al., 2014) for (a) surface air temperature (in ${ }^{\circ} \mathrm{C}$ ), (b) sea surface temperature (in ${ }^{\circ} \mathrm{C}$ ), (c) precipitation $(\%)$, and (d) surface orography (in $\mathrm{km}$ ). Anomalies with $<95 \%$ confidence in significance using a student $t$ test are masked in light grey. For orientation, a modern coastal outline is shown, latitude parallels are $20^{\circ}$ apart and longitude parallels are $30^{\circ}$ apart. Figure 10 also uses this projection.

sea levels by $25 \mathrm{~m}$, adjusting the topography to match MioPliocene orography (Fig. 4d), reducing ice sheet size and height $(-50 \%$ for Greenland and $-33 \%$ for Antarctica, also visible in Fig. 4d) and implementing Pliocene vegetation distribution. We chose to use these palaeoenvironmental boundary conditions from the United States Geological Survey (USGS) Pliocene Research, Interpretation and Synoptic Mapping (PRISM) 2 project, as per Haywood and Valdes (2004), even though they were originally reported for the earlier period of 3.26-3.02 Ma (Dowsett and Cronin, 1990; Dowsett et al., 1999). This is because more recent work by the USGS (PRISM3) implies that the PRISM2 palaeoenvironmental conditions are closer to an early Pliocene configuration than a mid-Pliocene one, particularly in terms of topography in the Americas and Himalayas (Haywood et al., 2010, 2011; Robinson et al., 2011).

Recently presented neodymium isotope evidence (Dutay et al., 2012; Osborne et al., 2012) suggests that a shallow CAS remained open until around $3 \mathrm{Ma}$. Therefore, one change made to the model configuration of Haywood and Valdes (2004) was to open the CAS, as per Lunt et al. (2008).

Atmospheric $\mathrm{CO}_{2}$ concentrations were set at $400 \mathrm{ppmv}$. Although this is at the high end of (or exceeding) proxyarchive reconstructions from the Messinian (incl. Demicco et al., 2003; Pagani et al., 1999; van de Wal et al., 2011), considerable uncertainties over these reconstructions remain (Bradshaw et al., 2012). Also, using a lower-resolution ocean version of the HadCM3 GCM (HadCM3L), Bradshaw et al. (2012) show that a better match between Miocene model and proxy climate data is achieved using $400 \mathrm{ppmv}$ compared with lower $\mathrm{CO}_{2}$ concentrations.

In light of these current palaeoenvironmental findings, the PRISM2 Pliocene set up with an open CAS ( $370 \mathrm{~m}$ deep) and 400 ppmv level of atmospheric $\mathrm{CO}_{2}$ would seem to capture the key ingredients of the late Miocene/early Pliocene world. Details of the PRISM2 Pliocene HadCM3 model setup and modifications to this configuration to include an open CAS are given by Haywood and Valdes (2004) and Lunt et al. (2008), respectively. (Note that Lunt et al., 2008, present their findings in the chronological framework of the CAS closing through time. However, their results can also be viewed in the converse framework of opening the CAS relative to the results of Haywood and Valdes (2004). This is the exact simulation that has been used as the Miocene control in this investigation, but Miocene control has been run for several millenia longer.)

The Messinian simulation was integrated for over 2400 years to enable the ocean to reach near-steady state and to provide the basis for all other simulations presented here. The Messinian control simulation is a 500-year continuation of this spin-up model run, with all other simulations also running for 500 years in parallel to this (reaching near-steady state within the first 400 years). In every case, the climate means were calculated from the final 100 years.

As outlined, the model set-up is identical to that used by Lunt et al. (2008), which is modified from Haywood and Valdes (2004), and thorough descriptions of the ocean circulation and climate simulated by the Messinian control are given by those authors. Briefly, in the late Miocene the world was warmer and wetter than it is today, although an overall cooling trend had set in and the bio-climatic zones of the Messinian were much closer to the present day than earlier Miocene conditions (e.g. Pound et al., 2012). With a global annual mean temperature of $16.7^{\circ} \mathrm{C}$, our modelled Messinian world (Messinian control) is $\sim 3.4^{\circ} \mathrm{C}$ warmer (Fig. 4a) and has $+0.2 \mathrm{~mm} \mathrm{day}^{-1}$ more rainfall $\left(+73 \mathrm{~mm} \mathrm{yr}^{-1}\right.$, both global annual means) than the equivalent modern simulation, where the high-latitude land masses and parts of the tropics are generally wetter, although some of the deserts and tropics have relatively less rainfall (Fig. 4c).

In terms of ocean circulation, both proxy- and modelbased research suggests that with an open CAS, Messinian North Atlantic Deep Water (NADW) formation would have been considerably weaker than for the present day (Böhme et al., 2008; Herold et al., 2012; Lunt et al., 2008; Molnar, 2008; Murdock et al., 1997; Prange and Schulz, 2004; Schneider and Schmittner, 2006; Steph et al., 2010; Zhang et al., 2012). We find that the maximum Atlantic Overturning Circulation is $\sim 17.5 \mathrm{~Sv}$, compared to $\sim 18.5 \mathrm{~Sv}$ in the modern equivalent (e.g. Ivanovic et al., 2014), but that in places, North Atlantic Meridional Overturning Circulation is much reduced (i.e. up to $4.8 \mathrm{~Sv}$ weaker) than in the modern. Also, the AMOC is completely changed south of the CAS, 

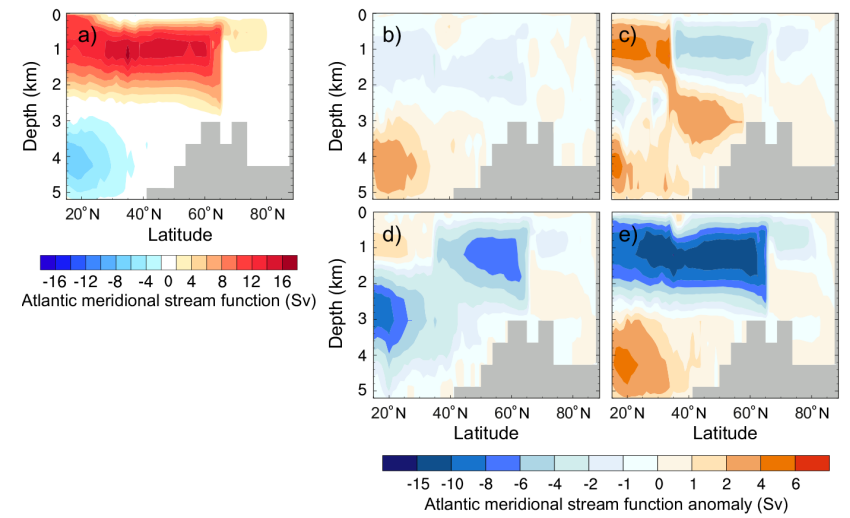

Fig. 5. Atlantic Meridional Overturning Circulation (AMOC) stream function (in Sv) for (a) Messinian control; and AMOC stream function anomalies, given with respect to Messinian control, for (b) no-exchange, (c) halite-quarter, (d) gypsum-half and (e) fresh-normal. Positive (negative) stream function indicates strength in the clockwise (counterclockwise) direction. Note that because of the open Central American Seaway in the Miocene, the Atlantic basin is only enclosed north of $15^{\circ} \mathrm{N}$; hence the stream function is plotted from $15^{\circ} \mathrm{N}$ to $90^{\circ} \mathrm{N}$. Bathymetry is masked in grey.

with strong Southern Ocean sources, due to the opened exchange with the Pacific. We will therefore focus the analysis of the Overturning Circulation and Deep Water Formation on that part of the Atlantic basin which remains enclosed (as captured by Fig. 5a). The global annual mean sea surface temperature in Messinian control is around $19.8^{\circ} \mathrm{C}$, approximately $2{ }^{\circ} \mathrm{C}$ warmer than for the modern (Fig. 4b).

In terms of Mediterranean-Atlantic water exchange, the Messinian control simulation preserves the model's modern two-layer flow structure of surface eastward flow of water into the Mediterranean and deeper westward flow into the Atlantic. Around $1.2 \mathrm{~Sv}$ of water is exchanged and the flow is enhanced compared to the equivalent modern simulation (Ivanovic et al., 2014) because the westernmost Mediterranean is on average around 2 psu saltier than for the present day (with a volume integral of around $44 \mathrm{psu}$ ), while the easternmost North Atlantic is 1-2 psu fresher (with a volume integral of around $35 \mathrm{psu}$ ). Consequently, MOW exports $1.2 \mathrm{psu} \mathrm{Sv}$ to the Atlantic, producing a clearly distinguishable, relatively warm, high-salinity plume that spreads westwards in the intermediate-deep North Atlantic (Fig. 6c and d). This comparatively high-salinity plume is similar (although $\sim 0.2 \mathrm{~Sv}$ stronger) to that which is observed (e.g. Boyer et al., 2009) and modelled (e.g. Ivanovic et al., 2014; as shown by Fig. $6 a$ and $b$ ) in the modern ocean.

\subsubsection{No Mediterranean Outflow Water}

Whether or not the Mediterranean ever fully or partially desiccated during the MSC, it seems likely that, at least at times, there was no outflow from the Mediterranean to the Atlantic (e.g. van Assen et al., 2006; Benammi et al., 1996; Betzler

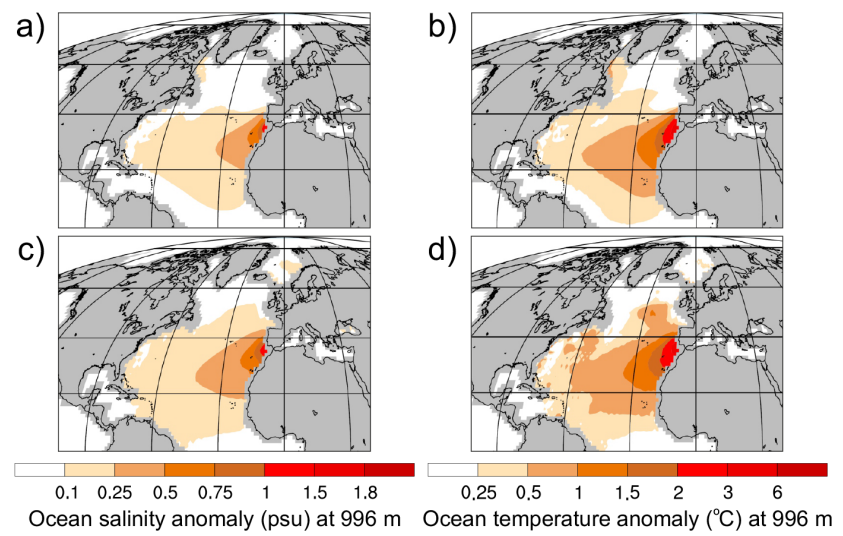

Fig. 6. North Atlantic annual mean difference between a simulation with MOW versus a simulation without MOW for $(\mathbf{a}, \mathbf{c})$ ocean salinity (in psu) and (b, d) ocean potential temperature (in ${ }^{\circ} \mathrm{C}$ ) both at a depth of $996 \mathrm{~m}$, for a modern (pre-industrial) control simulation (top: a, b) (Ivanovic et al., 2014) and a Messinian simulation (bottom: c, d). Continental landmasses are masked in grey. Note that for orientation, a modern coastal outline is shown, latitude parallels are $20^{\circ}$ apart and longitude parallels are $30^{\circ}$ apart. Figures 7 and 9 also use this projection.

et al., 2006; Hüsing et al., 2010; Ivanovic et al., 2013a; Krijgsman et al., 1999b). Although blocking MOW in a modern HadCM3 simulation had little impact on North Atlantic ocean circulation and climate (Ivanovic et al., 2014), consistent with other similar GCM simulations (Chan and Motoi, 2003; Kahana, 2005; Rahmstorf, 1998), there is considerable model and proxy evidence to suggest that it has the potential to play a more important role during periods of weaker AMOC (e.g. Bigg and Wadley, 2001; Penaud et al., 2011; Rogerson et al., 2010; Voelker et al., 2006). HadCM3 reproduces the modern AMOC reasonably well; for example, resulting in an overturning strength of $18 \pm 2 \mathrm{~Sv}$ at $26.5^{\circ} \mathrm{N}$ (Ivanovic et al., 2014) compared to $18.7 \pm 5.6 \mathrm{~Sv}$ in recent observations (Cunningham et al., 2007). The Messinian HadCM3 AMOC is 1-5 Sv weaker than the modern AMOC, so to investigate whether MOW has a greater effect during weaker AMOC modes than the present day, we ran a 500year simulation with no Mediterranean-Atlantic water exchange taking place, but with an otherwise identical set-up to the Messinian control. We will refer to this simulation as no-exchange.

\subsubsection{Extreme salinity events}

Modern North Atlantic circulation and climate appear to be much more sensitive to extreme changes in MOW salinity than they are to volumetric (and flow-rate) changes in Mediterranean-Atlantic exchange, including total blocking of MOW (Ivanovic et al., 2014). However, modelled North Atlantic circulation and climate are different in the Messinian compared to the present day (Sects. 2.3.1 and 2.3.2) and the 
Mediterranean salinity events thought to have occurred during the MSC are far more extreme than the scenarios examined by Rahmstorf (1998), Bigg and Wadley (2001), Rogerson et al. (2010) or Ivanovic et al. (2014). The Mediterranean Messinian succession comprises substantial thicknesses of (a) halite and (b) gypsum evaporites, as well as an interval containing (c) near-fresh (or brackish) fauna (Fig. 1). Therefore, to assess the potential global-scale influence of the MSC, we ran three sets of extreme salinity simulations, approximately corresponding to the salinity conditions required for (a), (b) and (c) to occur. Note that hereafter, the near-fresh simulations are referred to as fresh for simplicity. To reproduce the changes in Mediterranean salinity, the same method as Ivanovic et al. (2014) was adopted, forcing the entire Mediterranean basin (but nowhere else) to have a constant salinity of (a) 380 psu, (b) 130 psu (Flecker et al., 2002) and (c) 5 psu at every time step for the duration of the run.

The Mediterranean salinity fluctuations that took place during the MSC are widely thought to have been caused by tectonically and climatically driven changes in the volume of Mediterranean-Atlantic exchange water (e.g. Hsu et al., 1977; Krijgsman et al., 1999a). In line with geological evidence and box modelling (e.g. Flecker and Ellam, 2006; Fortuin and Krijgsman, 2003; Krijgsman and Meijer, 2008; Lugli et al., 2010; Meijer, 2012; Topper et al., 2011), we suggest that a more restricted exchange would generally have resulted in a higher Mediterranean salinity (e.g. gypsum, then halite stauration). However, the variation in exchange volume during Mediterranean hyposalinity is not well understood and the exact exchange rate during any part of the MSC is not yet known. Based on this, simulations were run without changing the coefficient of Mediterranean-Atlantic exchange ( $\mu$; the parameterisation of the volume of mixing between the two basins). These will be referred to as (a) halite-normal, (b) gypsum-normal and (c) fresh-normal. In addition, to reflect the likely direction of change (decrease or increase) of MOW volume and flow rates that would have occurred during the MSC events (discussed above), we also ran a subset of (a), (b) and (c) with appropriate, but idealised changes in the coefficient of exchange $(\mu)$; (a) quartering the coefficient for the most saline simulation (halite-quarter), (b) halving the coefficient for the less extreme hypersaline simulation (gypsum-half) and (c) both halving (fresh-half) and doubling (fresh-double) the coefficient for the hyposaline scenario because it is difficult to be confident in the direction of change to the exchange volune. The nine simulations are summarised in Table 1.

We acknowledge that of these three scenarios, MOW is least likely to have occurred during halite saturation. Other evidence (incl. Abouchami et al., 1999; Gladstone et al., 2007; Ivanovic et al., 2013a; Meijer and Krijgsman, 2005; Meijer, 2006, 2012; Muiños et al., 2008) indicates that at least episodic bursts of MOW may well have occurred during gypsum saturation and brackish water conditions. Nonetheless, we have tested all three scenarios on the basis that none can yet be disproved; the volume of evaporites found in the Mediterranean Messinian succession cannot be explained without Atlantic inflow and Meijer (2012) shows that a gateway has to be extremely shallow before outflow is blocked.

It should also be noted that holding Mediterranean salinity constant throughout the simulations introduces an unphysical salt source/sink mechanism to the global ocean. Over 500 years, the volume integral for the global ocean salinity changes by around $0.2 \mathrm{psu}$ in halite-quarter, $0.1 \mathrm{psu}$ in gypsum-half and 0.05 psu in fresh-normal. Thus, the changes are small $(0.1-0.5 \%)$ and the resulting Mediterranean salt source/sink does not present a problem for understanding the physical mechanisms at work in these idealised simulations. Importantly, the forced constant salinities do mean that changes in global ocean circulation or climate cannot feed back to Mediterranean salinity; investigating this will provide the basis for future work.

Importantly, Atlantic salinity remains below 42 psu in all simulations, even for the grid boxes immediately adjacent to the Spain-Morocco land bridge during Mediterranean halite and gypsum saturation. This is due to implicit mixing of Mediterranean and Atlantic water in the pipe connecting the basins (Eq. 1) and because the exchange is small compared to the volume of water in each model grid box. Hence, outside of the Mediterranean, ocean salinity stays within the valid range of the model equation of state (Sect. 2.1); Mediterranean circulation is not investigated in this study.

\section{Results}

All climate anomalies presented and discussed here are robust against a student $t$ test with $95 \%$ confidence based on modelled interannual variability, which was calculated for the final 100 years of the simulations.

\subsection{No Mediterranean outflow}

In the modern HadCM3 ocean, around $1 \mathrm{~Sv}$ of MOW flows westwards through the Gibraltar straits, whereupon it descends the continental shelf and spreads in a relatively warm plume, centred around $1200-1500 \mathrm{~m}$ deep, that is up to $1.8 \mathrm{psu}$ more saline than ambient NACW (Ivanovic et al., 2014). Whilst not perfect, this is quite a good reproduction of the observed $>0.74 \pm 0.05 \mathrm{~Sv}$ of MOW that flows through the Gibraltar straits into the Atlantic (García-Lafuente et al., 2011) and spreads westwards in a relatively saline (up to $+1.8 \mathrm{psu}$ ) plume, centred at around 1000-1200 m deep (e.g. Boyer et al., 2009).

Comparing simulations with and without the presence of Mediterranean-Atlantic exchange allows us to examine the MOW contribution to the Atlantic, both in the context of the present day (Ivanovic et al., 2014) and the Messinian (this study); for example, by using salinity and temperature anomaly plots in control-no-exchange experiments. This 
Table 1. Summary of the differences between all simulations. For Messinian control and no-exchange, Mediterranean salinity was left unforced, resulting in normal, open marine salinity conditions of $\sim 44 \mathrm{psu}$ for the basin.

\begin{tabular}{|c|c|c|c|c|}
\hline $\begin{array}{l}\text { Experiment } \\
\text { name }\end{array}$ & $\begin{array}{r}\text { Mediterranean } \\
\text { outflow }\end{array}$ & $\begin{array}{r}\text { Mediterranean } \\
\text { salinity }\end{array}$ & $\begin{array}{l}\text { Coefficient of } \\
\text { exchange }(\mu)\end{array}$ & $\begin{array}{l}\text { Mediterranean salt } \\
\text { export to Atlantic }\end{array}$ \\
\hline control & present & unforced & $\mu_{\mathrm{C}}$ & $1.2 \mathrm{psu} \mathrm{Sv}$ \\
\hline no-exchange & blocked & unforced & no exchange & $\begin{array}{ll}1 & 0\end{array}$ \\
\hline halite-quarter & present & $380 \mathrm{psu}$ & $0.25 \mu_{\mathrm{C}}$ & 20.6 psu Sv \\
\hline halite-normal $^{\mathrm{a}}$ & present & $380 \mathrm{psu}$ & $\mu_{\mathrm{C}}$ & 84.2 psu Sv \\
\hline gypsum-half & present & $130 \mathrm{psu}$ & $0.5 \mu_{\mathrm{C}}$ & $11.0 \mathrm{psu} \mathrm{Sv}$ \\
\hline gypsum-normal ${ }^{\mathrm{a}}$ & present & $130 \mathrm{psu}$ & $\mu_{\mathrm{C}}$ & $22.4 \mathrm{psu} \mathrm{Sv}$ \\
\hline fresh-half $^{\mathrm{a}}$ & present & $5 \mathrm{psu}$ & $0.5 \mu_{\mathrm{C}}$ & $-3.0 \mathrm{psu} \mathrm{Sv}$ \\
\hline fresh-normal & present & $5 \mathrm{psu}$ & $\mu_{\mathrm{C}}$ & $-7.0 \mathrm{psu} \mathrm{Sv}$ \\
\hline fresh-double $\mathrm{a}^{\mathrm{a}}$ & present & $5 \mathrm{psu}$ & $2 \mu_{\mathrm{C}}$ & $-14.2 \mathrm{psu} \mathrm{Sv}$ \\
\hline
\end{tabular}

is confirmed by previous simulations with conservative dye tracers (e.g. the work for Ivanovic et al., 2014), which show that such anomaly plots accurately reflect the spread of MOW in the Atlantic. This also lends credence to the identification of the modern MOW plume in observational data sets (e.g. Boyer et al., 2009) as a tongue of relatively warm, salty water protruding into the Atlantic.

In the Messinian HadCM3 ocean (Fig. 6c and d; this study), the 0.2 psu saltier MOW makes a greater contribution to the North Atlantic above $1200 \mathrm{~m}$ than it does in the modern (Fig. 6a and b; reproduced from Ivanovic et al., 2014). Consequently, the MOW plume becomes entrained in the shallower, northward flowing currents of the AMOC and reaches further north. This means it makes a greater direct contribution to the Greenland-Iceland-Norwegian (GIN) and Barents Seas (locations indicated by Fig. 2) and also provides relatively warm, salty water to sites of central North Atlantic upwelling. Thus the difference in MOW buoyancy between the Messinian and present day is important in regulating its wider impact. We also find that the absence of MOW in noexchange reduces Messinian AMOC by $\sim 2 \mathrm{~Sv}$ (Fig. $5 \mathrm{~b}$ ), compared to $0.7 \mathrm{~Sv}$ in the modern ocean (Ivanovic et al., 2014). In agreement with Bigg and Wadley (2001), Voelker et al. (2006), Rogerson et al. (2006, 2010, 2012), Penaud et al. (2011) and others, this suggests that MOW does indeed have a greater effect on North Atlantic Ocean circulation during weaker modes of AMOC than it does under the stronger, present-day regime.

Without MOW in the North Atlantic in no-exchange, less relatively warm, salty water reaches sites of upwelling and therefore, cooler, fresher water is brought to the surface than in Messinian control (Fig. 7). A site centred at around $50^{\circ} \mathrm{N}$, $40^{\circ} \mathrm{W}$ is particularly affected by this, where the upwelling of relatively colder water in no-exchange cools the overlying atmosphere by up to $0.9^{\circ} \mathrm{C}$ (annual mean Surface Air Temperature, SAT) relative to Messinian control. Furthermore, with a weakened AMOC and a cooler, fresher intermediate North Atlantic (e.g. Fig. 7d), less relatively warm, salty, shallowintermediate, low-latitude water reaches the higher northern

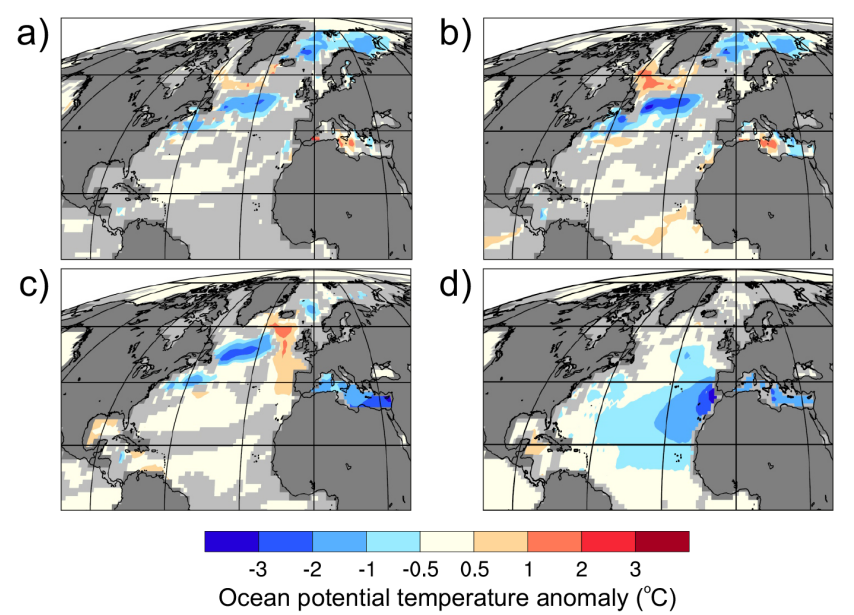

Fig. 7. North Atlantic annual mean ocean potential temperature anomalies (in ${ }^{\circ} \mathrm{C}$ ) for no-exchange with respect to Messinian control at a depth of (a) $5 \mathrm{~m}$ (b) $67 \mathrm{~m}$, (c) $301 \mathrm{~m}$ and (d) $996 \mathrm{~m}$. Continental land masses are masked in dark grey. Anomalies with $<95 \%$ confidence in significance using a student $t$ test are masked in light grey.

latitudes and there is reduced exchange between the Atlantic and the GIN Seas. In the subsurface, this results in cooling (and freshening) of the GIN and Barents Seas (Fig. 7), with the temperature signal being transferred upwards to cause an overal cooling of up to $1{ }^{\circ} \mathrm{C}$ (annual mean SAT) in the overlying atmosphere. The reduced exchange between the Atlantic and GIN Seas means less relatively cold, high-latitude water escapes southwards from the GIN Seas and consequently, the shallow ocean off the Greenland coast and in the Labrador Sea is $\sim 1^{\circ} \mathrm{C}$ warmer than in Messinian control (warming seen in Fig. 7a and b). Warming of $\sim 1^{\circ} \mathrm{C}$ also occurs along the Atlantic's eastern boundary (Fig. 7c) where cooler highlatitude water (e.g. from the GIN Seas) has been replaced by relatively warm, Atlantic water, with respect to Messinian control. However, little of this warming signal is transferred 
to the surface ocean (Fig. 7a) and there is no statistically significant imprint on surface air temperatures.

\subsection{Extreme salinity events}

In order to assess the robustness of the model results, seven Mediterranean salinity simulations were run in total (Table 1); two halite saturation scenarios (halite-normal and halite-quarter), two gypsum saturation scenarios (gypsumnormal and gypsum-half) and three brackish lagoon scenarios (fresh-half, fresh-normal and fresh-double). A detailed analysis was carried out on all seven of these simulations and the full data can be accessed at http://www.bridge.bris.ac.uk/ resources/simulations. However, for each high/low Mediterranean salinity scenario ( $380 \mathrm{psu}, 130 \mathrm{psu}, 5 \mathrm{psu})$, the results were remarkably similar. Generally, the climate anomalies had the same direction of change and were brought about through the same mechanisms, although the magnitude of change was different depending on the exchange strength (varied $\mu$, see Table 1); reducing the exchange damped the anomalies, enhancing the exchange exaggerated the anomalies. Therefore for clarity, the following discussion is focused on the three most pertinent simulations (one per set of scenarios). For the hypersaline Mediterranean scenarios we chose those simulations with a direction of change in the coefficient of exchange $(\mu)$ that best represents the physical constriction of the gateways that is most likely to have occurred (see the discussion in Sect. 2.3.3); this is halite-quarter and gypsumhalf. These reduced-exchange simulations also produce far less extreme (though still very large) salinity fluxes through the gateways than their unrestricted (i.e. unchanged $\mu$ ) counterparts, halite-normal and gypsum-normal (Table 1). For the hyposaline Mediterranean scenarios the most appropriate simulation to discuss is fresh-normal. This is because we do not know whether Mediterranean-Atlantic exchange increased or decreased during these events. All anomalies are given with respect to Messinian control.

\subsubsection{Mediterranean hypersalinity}

The model responds to extreme increases in Mediterranean (Outflow Water) salinity by enhancing the two-layered Mediterranean-Atlantic exchange (1.2 Sv in Messinian control) by approximately $10 \mathrm{~Sv}$ in halite-quarter and $5.3 \mathrm{~Sv}$ in gypsum-half. The imposed, uniform haline forcing (Table 1) of the experiment design causes a reduction in downward mixing of relatively warm Mediterranean surface waters and induces cooling of the Mediterranean basin, on average by around $2.0^{\circ} \mathrm{C}$ in halite-quarter and $1.8^{\circ} \mathrm{C}$ in gypsum-half. In addition, the increased exchange with the Atlantic elevates Mediterranean salt export (1.2 psu Sv in Messinian control) by $19.4 \mathrm{psu} \mathrm{Sv}$ and $9.8 \mathrm{psu} \mathrm{Sv}$, respectively (Table 1 ). Mainly as a result of its salting, MOW becomes much stronger and denser, deepening in the North Atlantic and spreading predominantly southwards from the Mediterranean-Atlantic

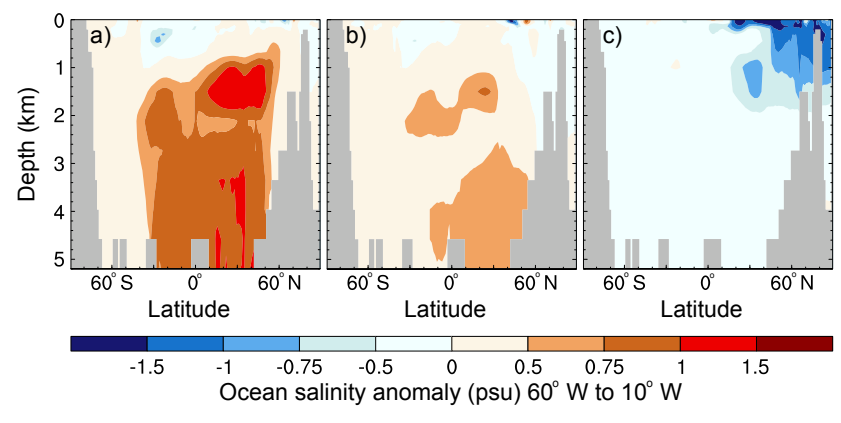

Fig. 8. Annual mean ocean salinity anomalies (in psu) from the North to South Pole, averaged over $60^{\circ} \mathrm{W}$ to $10^{\circ} \mathrm{W}$ and given with respect to Messinian control for (a) halite-quarter, (b) gypsum-half and (c) fresh-normal. Bathymetry is masked in grey. All anomalies are given with $>95 \%$ confidence in their significance using a student $t$ test.

corridors $\sim 35^{\circ} \mathrm{N}$ (e.g. Fig. 8a and b). Although the MOW plume is cooler than in Messinian control, it is also saltier, so that at neutral buoyancy it resides in less saline, cooler Atlantic water. Thus overall, the salinity and temperature of the intermediate-deep Atlantic and Southern Oceans are raised.

This has effectively shifted a component of NADW formation to the Mediterranean basin. In halite-quarter and gypsum-half, NADW formation is weakened by up to 5.6 and $7.7 \mathrm{~Sv}$, respectively, while the AMOC south of $35^{\circ} \mathrm{N}$ is strengthened by around 6 and $1.5 \mathrm{~Sv}$; Fig. $5 \mathrm{c}$ and d. These changes in mid-high latitude ocean overturning circulation reduce the poleward transport of shallow, relatively warm and salty low-latitude waters north of the MediterraneanAltantic corridors $\sim 35^{\circ} \mathrm{N}$ and as a consequence, parts of the high-latitude North Atlantic-Labrador-GIN seas region cool by a few degrees (See Fig. 9b and c). The North Atlantic subtropical gyre transports this cooling signature southwest across the North Atlantic, towards the open CAS.

Similar to no-exchange, in gypsum-half, reduced subsurface outflow from the GIN Seas to the North Atlantic actually results in localised shallow warming of a small area in the northernmost North Atlantic, south of Greenland. This transfers to the overlying atmosphere and increases annual mean SATs by up to $1.4^{\circ} \mathrm{C}$ (Fig. 9c). By the same process, eastern boundary intermediate water is also warmed by up to $1.7^{\circ} \mathrm{C}$ (annual mean), but this is too deep to be transferred to surface water or air temperatures. High-latitude cooling in the other hypersaline Mediterranean simulations (including halite-quarter) is so strong that it overrides this surface air-temperature warming, and only cooling is observed in the region (e.g. Fig. 9b).

\subsubsection{Mediterranean hyposalinity}

Freshening the Mediterranean in fresh-normal both reverses and steepens the density gradient between the Mediterranean and the Atlantic, resulting in an opposite two-layer exchange 
a)
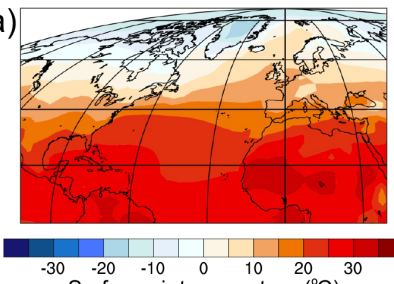
Surface air temperature $\left({ }^{\circ} \mathrm{C}\right)$

C)

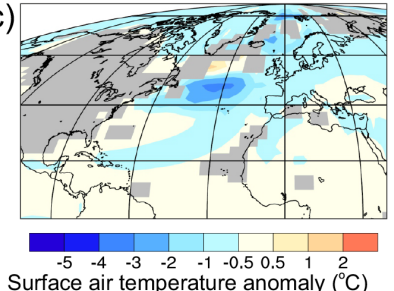

b)

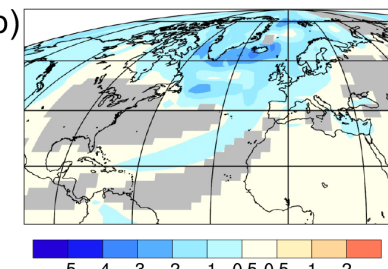

Surface air temperature anomaly $\left({ }^{\circ} \mathrm{C}\right)$

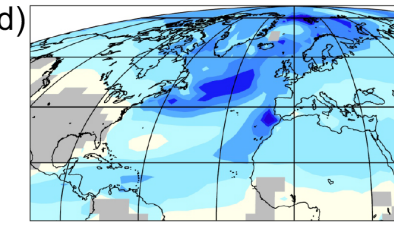

$\begin{array}{lllllllllll}-5 & -4 & -3 & -2 & -1 & -0.5 & 0.5 & 1 & 2\end{array}$ Surface air temperature anomaly $\left({ }^{\circ} \mathrm{C}\right)$

Fig. 9. North Atlantic annual mean surface air temperatures (in ${ }^{\circ} \mathrm{C}$ ) for (a) Messinian control and annual mean surface air temperature anomalies, given with respect to Messinian control, for (b) halitequarter, (c) gypsum-half and (d) fresh-normal. The magnitudes of some of the local anomalies are difficult to identify, especially in the high latitudes, but numbers quoted in the text are accurate. Anomalies with $<95 \%$ confidence in significance using a student $t$ test are masked in light grey.

structure (surface westward flow and deeper eastward flow) that has been enhanced by $6.3 \mathrm{~Sv}$. Consequently, the Mediterranean cools, on average, by around $4.0^{\circ} \mathrm{C}$. However, it also becomes a salinity sink (or freshwater source) to the Atlantic, now importing around $7.0 \mathrm{psu} \mathrm{Sv}$, compared to the export of $1.2 \mathrm{psu} \mathrm{Sv}$ in Messinian control. This more than counteracts the reduction in MOW buoyancy (increase in MOW density) arising from Mediterranean cooling and freshens the entire North Atlantic water column (Fig. 8c). In particular, this affects the shallow $(0-400 \mathrm{~m})$ levels that now receive this brackish water injection from the Mediterranean and the intermediate-deep levels (800-2000 m) that are now without the relatively saline MOW plume that is present in Messinian control.

Unlike the modern fresh-Med simulations run by Ivanovic et al. (2014), the effect on Atlantic Ocean circulation is rather straight forward, profound and widespread. This is mainly due to the relatively weaker AMOC (by 2.7-4.8 Sv) compared to the present day and the more important role MOW played in governing Messinian overturning circulation (Sect. 3.1) with respect to the modern (Ivanovic et al., 2014). Interestingly, although our Mediterranean salinity perturbation is 15 psu larger than the Mediterranean freshening simulations run by Ivanovic et al. (2014), this plays only a very minor role in generating the difference between the modern and Messinian climate anomalies. Modern simulations with a 5 psu Mediterranean (unpublished data, available at http://www.bridge.bris.ac.uk/resources/simulations) show anomaly patterns with the same locality and direction of change as with a 19 psu Mediterranean (warming in the GIN

a)
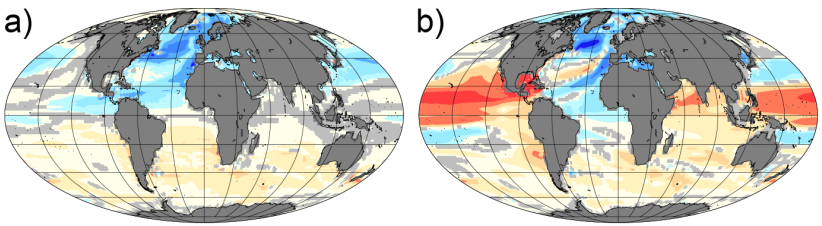

c)

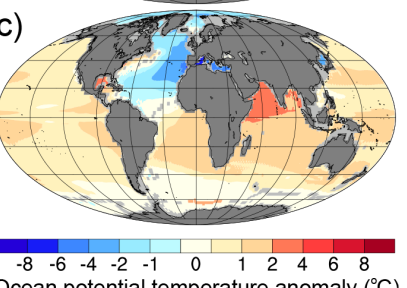

$$
\text { Ocean potential temperature anomaly }\left({ }^{\circ} \mathrm{C}\right)
$$

Fig. 10. Annual mean ocean potential temperature anomalies (in ${ }^{\circ} \mathrm{C}$ ) for fresh-normal with respect to Messinian control at a depth of (a) $5 \mathrm{~m}$ (b) $204 \mathrm{~m}$ and (c) $996 \mathrm{~m}$. Continental land masses are masked in dark grey. Anomalies with $<95 \%$ confidence in significance using a student $t$ test are masked in light grey.

Seas, cooling in the North Atlantic, but no further-spread climate signal; Ivanovic et al., 2014), but are of greater magnitude. In the Messinian simulations, freshening of the shallow-intermediate North Atlantic causes a total collapse of NADW formation and the AMOC (Fig. 5e).

The collapse of the AMOC and consequent reduction in northward heat transport from the equator in the shallowintermediate North Atlantic more than counteracts any warming from the increased direct supply of more southerly sourced, shallow water to the GIN seas (e.g. Sect. 3.3.1 and Fig. 6b in Ivanovic et al., 2014), especially as MOW itself is now cooler. The resulting annual mean high-latitude cooling of up to $8^{\circ} \mathrm{C}$ in the shallow-intermediate subsurface (e.g. Fig. 10a and b) is transferred to the overlying atmosphere, causing widespread cooling of $1-3^{\circ} \mathrm{C}$ (and up to $8^{\circ} \mathrm{C}$ in places) in the Northern Hemisphere (Fig. 9d), even reaching across the equator in a few locations; over the African continent, Brazil, Australia and the mid-Pacific. In addition, the North Atlantic subtropical gyre transports relatively cold, shallow water (including a direct contribution from MOW) southwest across the North Atlantic, through the open CAS and into the Pacific (Fig. 10a), creating a relatively cool, low-latitude current that can be seen in the SAT anomalies (Fig. 9d).

Conversely, parts of the Southern Hemisphere are warmer in fresh-normal, compared to Messinian control. This bipolar phenomenon has also been instigated by the collapse of the AMOC, whereby relatively cold NADW is no longer transported south, at depth, to the Southern Ocean. As a result, the intermediate-deep South Atlantic, Southern and Indian oceans are up to $2^{\circ} \mathrm{C}$ warmer than in Messinian control (Fig. 10c). This warming is transferred to the surface ocean at sites of upwelling (e.g. Fig. 10a and b), resulting in SAT anomalies of $0.7-1.0^{\circ} \mathrm{C}$ in these regions. In addition, weak, very deep AABW formation in the Pacific 
sector of the Southern Ocean (Amundsen Sea) is switched on in the hyposaline Mediterranean simulations and there is an overall reduction in South Pacific upwelling. Thus, where upwelling in the Messinian control brings relatively cold, Pacific deep (and bottom) water through the water column towards the surface, with a hyposaline Mediterranean the intermediate-shallow South Pacific becomes $0.5-2.7^{\circ} \mathrm{C}$ warmer (Fig. 10b), heating the air above by $0.5-1.9^{\circ} \mathrm{C}$.

In the Pacific, there is also reduced transport of relatively saline, low-latitude surface waters south. This raises equatorial surface water salinity and contributes towards water column instability, boosting the strength of a latitudinally narrow overturning cell in the region. This mixes relatively warm, shallow water down through the water column, warming the Pacific equatorial subsurface by up to $6.5^{\circ} \mathrm{C}$ (e.g. Fig. 10b). Thus, heat from the equator is transferred downwards, rather than polewards. Subsurface, eastward flow through the open CAS carries some of this warmer water into the Caribbean Sea and Gulf of Mexico (locations indicated by Fig. 2), but the positive temperature anomaly is confined here and does not reach the open Atlantic (Fig. 10b). This process also occurs in the Indian Ocean, but to a lesser extent.

Neither of the hypersaline Mediterranean simulations (halite-quarter and gypsum-half) show a discernible reorganisation of atmospheric circulation with respect to Messinian control, nor do they have a significant effect on precipitation. Conversely, the bipolar Northern Hemisphere cooling and Southern Hemisphere warming of the hyposaline simulations does induce a $2^{\circ}$ (approx.) southward shift of precipitation falling along the northern edge of the intertropical convergence zone. This signal is strongest over the Pacific, where the northern tropics dry and the southern tropics moisten by up to $6 \mathrm{~mm} \mathrm{day}^{-1}$. Importantly, the affected regions have also been influenced by the reduction in poleward thermal/haline transports, causing a build-up of heat and salt near the equator. The southward shift in precipitation-evaporation over the tropics enhances the local salinity anomalies that result in the latitudinally narrow convection cell discussed above.

\section{Discussion and conclusions}

In our HadCM3 simulations, blocking MediterraneanAtlantic exchange during the Messinian Salinity Crisis reduces AMOC strength by up to $2.3 \mathrm{~Sv}$. This is different to HadCM3 simulations of the modern ocean without MOW, which instead show a smaller weakening $(0.7 \mathrm{~Sv})$ in deep AMOC components south of the Gibraltar Straits that is concurrent with a small (1-2 Sv) strengthening of NADW formation (Ivanovic et al., 2014). The modern climate is seemingly insensitive to the presence of MOW in the North Atlantic (e.g. Artale et al., 2002; Chan and Motoi, 2003; Ivanovic et al., 2014; Kahana, 2005; Rahmstorf, 1998; Wu et al., 2007), but the Messinian AMOC's response to blocking MOW produces very localised SAT cooling of up to $0.9^{\circ} \mathrm{C}$ over the central North Atlantic Ocean and GIN Seas and up to $1^{\circ} \mathrm{C}$ over the Barents Sea. These differences between the Messinian and the modern arise from (a) Messinian MOW making a greater contribution to the upper $1200 \mathrm{~m}$ in the North Atlantic due to raised Atlantic salinity compared to the modern and (b) the weaker Messinian AMOC (and its influence on climate) being more susceptible to Atlantic salinity and temperature perturbations; in this instance, the absence of Mediterranean-origin water.

The Mediterranean salinity perturbations have a much greater and widespread impact on climate, with consistency in the results across all seven simulations (Table 1). Halitequarter and gypsum-half, which are probably the most realistic of the hypersalinity simulations (see the discussions in Sects. 2.3.3 and 3.2), both have a very similar affect on ocean circulation and climate compared to Messinian control. Broadly, elevating Mediterranean salinity enhances Mediterranean-Atlantic exchange and salt export, shifting a component of deep water formation out of the North Atlantic and into the Mediterranean. This weakens NADW formation by $5-8 \mathrm{~Sv}$. The resulting impact on water exchange between the North Atlantic and high-latitude seas, combined with the more global effect on ocean heat transport, cools Northern mid-high latitude SATs by a few degrees.

In addition, the reduced exchange between the North Atlantic and GIN Seas in gypsum-half causes some localised warming of up to $1.7^{\circ} \mathrm{C}$ in the shallow-intermediate northernmost North Atlantic Ocean (warming the overlying air) and along the North Atlantic eastern boundary. This also takes place with a blocked Mediterranean-Atlantic exchange, but in the other hypersaline Mediterranean simulations, including halite-quarter, surface cooling is too strong and overrides any relative warming that may take place. It is important to consider that these results may be influenced by the overly diffuse MOW plume simulated by HadCM3. For example, a more coherent MOW core would probably not interact with intermediate and deep Atlantic Ocean circulation as significantly as in these simulations, but would instead sink and pool at the bottom of the North Atlantic. On the other hand, this effective enhancement of North Atlantic entrainment in MOW could be an important counteraction to the underestimation of shallow-intermediate mixing between MOW and NACW in what is now the Gibraltar StraitGulf of Cadiz region.

Brackish MOW in the hyposaline Mediterranean simulations produces a bipolar climate signal, with widespread cooling of $1-3^{\circ} \mathrm{C}$ (and up to $8^{\circ} \mathrm{C}$ ) in Northern Hemisphere SATs and patchy warming of $0.5-2.7^{\circ} \mathrm{C}$ at sites of intermediate-deep water upwelling in the Southern Hemisphere. These temperature anomalies are predominantly caused by AMOC collapse (in response to Atlantic freshening by Mediterranean-origin water), which reduces northward heat transfer in the shallow ocean and stops 
relatively cold NADW from being transferred south in the intermediate-deep layers. Notably, these effects are much greater and, in the GIN Seas, are even opposite in direction to the anomalies simulated with a 5 psu Mediterranean and a modern (pre-industrial) model configuration. The hyposaline Mediterranean simulations are the only simulations to exhibit changes in precipitation patterns beyond interannual variability; a southward shift, by a few degrees, of the intertropical convergence zone. This shift and the bipolar climate anomalies, both predominantly caused by AMOC collapse, are consistent with (if larger than) results from high northern latitude freshwater-hosing experiments (e.g. Clement and Peterson, 2008; Kageyama et al., 2013; Stouffer et al., 2006; Zhang and Delworth, 2005).

The conditions of Mediterranean-Atlantic exchange modelled here in the hyper- and hypo-saline experiments are not meant to represent realistic MSC scenarios. Rather, they have been designed to push the limits of the climate response to very extreme instances of changes in MOW conditions. The enhanced exchange strength simulated in this study $(\sim 11.2 \mathrm{~Sv}$ for halite-quarter, $6.5 \mathrm{~Sv}$ for gypsum-half and $7.5 \mathrm{~Sv}$ for fresh-normal) are unlikely conditions for sustained halite saturation, gypsum saturation or brackish Mediterranean water conditions in the MSC (e.g. Garcia-Castellanos and Villaseñor, 2011; Meijer, 2012; Topper et al., 2011). Instead, events of extremely elevated or negative Mediterranean salt export are most likely to have occurred intermittently (as postulated by Thierstein and Berger, 1978), for example at the end of each episode of Mediterranean high/low salinity. Such hyper-/hypo-saline transition phases between normal marine and extreme Mediterranean conditions are in contrast to the forced, constant extreme salinity MOW events modelled in this sensitivity study. However, if considering Messinian MOW hyper- and hypo-salinity as a series of short events, time series information from some of our coupled AOGCM simulations (available at http://www.bridge.bris. ac.uk/resources/simulations) suggests that, initially, there is a decadal-scale overshoot in ocean circulation. It therefore seems likely that the shorter-term (transient) ocean circulation impact of MSC events could actually be far more extreme than the results discussed here. We have not aimed to explore the early time-series response of the global ocean to the MSC; these simulations are "equilibrium" experiments, but future work could focus on transient scenarios to examine a more realistic timeline of events. Currently, this is difficult as we do not have sufficient evidence to constrain the evolution of Mediterranean-Atlantic connectivity during the MSC. However, new data (Ivanovic et al., 2013a) provides some hope that this could soon be rectified.

Data coverage for the late Miocene is sparse and patchy (Bradshaw et al., 2012). We suggest that the global-scale MSC climate signal could be absent (e.g. discussions within Murphy et al., 2009; Schneck et al., 2010) due to palaeoclimate reconstructions inadvertently targeting either the wrong geographic locations or the wrong climate variables.
In addition, the reconstructions may have insufficient temporal resolution to distinguish the events. With these fully coupled GCM simulations, we have begun to address these possibilities, providing key information on which geographical regions and climate variables are most susceptible to possible MSC-induced perturbations. Appropriate proxy archives and sample locations can be identified and targeted for geologic evidence of global-scale climate change brought about by Messinian Mediterranean hyper-/hypo-salinity and blocked MOW scenarios. Such data would not only provide a more robust test for global general circulation models and our process-based understanding of climate interactions (including the influence of MOW on North Atlantic circulation and climate), but would also lead to a better knowledge of MSC Mediterranean-Atlantic connectivity in the absence of more conclusive data (Abouchami et al., 1999; Ivanovic et al., 2013a; Muiños et al., 2008). North Atlantic sea surface and surface air temperatures consistently show the most variability in all eight of our MSC scenario simulations; whether there is no Mediterranean-Atlantic exchange, or hyper-/hypo-saline MOW (Fig. 9). We therefore propose that by focusing Messinian temperature reconstructions on this region, future proxy archive work could more definitively establish whether or not the MSC had the global-scale climate impact that our model results suggest it could have.

Acknowledgements. This work was funded by a University of Bristol Centenary Scholarship and was carried out using the computational facilities of the Advanced Computing Research Centre, University of Bristol, http://www.bris.ac.uk/acrc/. Full access to the data produced by these simulations is provided at http://www.bridge.bris.ac.uk/resources/simulations. We are very grateful to two anonymous reviewers for their valuable comments on the manuscript, and to Yves Godderis for swift editorial handling.

Edited by: Y. Godderis

\section{References}

Abouchami, W., Galer, S. J., and Koschinsky, A.: Pb and Nd isotopes in NE Atlantic Fe-Mn crusts: Proxies for trace metal paleosources and paleocean circulation, Geochim. Cosmochim. Acta, 63, 1489-1505, doi:10.1016/S0016-7037(99)00068-X, 1999.

Artale, V., Calmanti, S., and Sutera, A.: Thermohaline circulation sensitivity to intermediate-level anomalies, Tellus A, 54, 159174, doi:10.1034/j.1600-0870.2002.01284.x, 2002.

Benammi, M., Calvo, M., Prévot, M., and Jaeger, J.-J.: Magnetostratigraphy and paleontology of Ait Kandoula basin (High Atlas, Morocco) and the African-European late Miocene terrestrial fauna exchanges, Earth Planet. Sci. Lett., 145, 15-29, doi:10.1016/S0012-821X(96)00183-5, 1996.

Benson, R. H., Bied, K. R.-E., and Bonaduce, G.: An important current reversal (influx) in the Rifian Corridor (Morocco) at the Tortonian-Messinian boundary: The end of Tethys Ocean, Paleoceanography, 6, 165-192, doi:10.1029/90PA00756, 1991. 
Bethoux, J. P. and Gentili, B.: Functioning of the Mediterranean Sea: past and present changes related to freshwater input and climate changes, J. Mar. Syst., 20, 33-47, doi:10.1016/S09247963(98)00069-4, 1999.

Betzler, C., Braga, J. C., Martín, J. M., Sánchez-Almazo, I. M., and Lindhorst, S.: Closure of a seaway: stratigraphic record and facies (Guadix basin, Southern Spain), Int. J. Earth Sci., 95, 903910, doi:10.1007/s00531-006-0073-y, 2006.

Bigg, G. R. and Wadley, M. R.: Millennial-scale variability in the oceans: an ocean modelling view, J. Quat. Sci., 16, 309-319, doi:10.1002/jqs.599, 2001.

Blanc, P.-L.: Of sills and straits: a quantitative assessment of the Messinian Salinity Crisis, Deep Sea Res. Part Oceanogr. Res. Pap., 47, 1429-1460, doi:10.1016/S0967-0637(99)00113-2, 2000.

Böhme, M., Ilg, A., and Winklhofer, M.: Late Miocene "washhouse" climate in Europe, Earth Planet. Sci. Lett., 275, 393-401, doi:10.1016/j.epsl.2008.09.011, 2008.

Boyer, T. P., Antonov, J. I., Baranova, O. K., Garcia, H. E., Johnson, D. R., Locarnini, R. A., Mishonov, A. V., O’Brien, T. D., Seidov, D., Smolyar, I. V., and Zweng, M. M.: World Ocean Database 2009, NOAA Atlas NESDIS 66, edited by: Levitus, S., US Gov. Printing Office, Washington D.C., 216 pp., 2009.

Bradshaw, C. D., Lunt, D. J., Flecker, R., Salzmann, U., Pound, M. J., Haywood, A. M., and Eronen, J. T.: The relative roles of $\mathrm{CO}_{2}$ and palaeogeography in determining late Miocene climate: results from a terrestrial model-data comparison, Clim. Past, 8, 1257-1285, doi:10.5194/cp-8-1257-2012, 2012.

Bryan, K. and Cox, M. D.: An Approximate Equation of State for Numerical Models of Ocean Circulation, J. Phys. Oceanogr., 2, 510-514, doi:10.1175/15200485(1972)002<0510:AAEOSF>2.0.CO;2, 1972.

Canals, M., Puig, P., Madron, X. D., de Heussner, S., Palanques, A., and Fabres, J.: Flushing submarine canyons, Nature, 444, 354357, doi:10.1038/nature05271, 2006.

Cattle, H., Crossley, J., and Drewry, D. J.: Modelling Arctic Climate Change [and Discussion], Philos. Trans. Phys. Sci. Eng., 352, 201-213, 1995.

Chan, W.-L. and Motoi, T.: Effects of Stopping the Mediterranean Outflow on the Southern Polar Region, Polar Meteorol. Glaciol. Nat. Inst. Polar Res., 17, 25-35, 2003.

Clement, A. C. and Peterson, L. C.: Mechanisms of abrupt climate change of the last glacial period, Rev. Geophys., 46, RG4002, doi:10.1029/2006RG000204, 2008.

Cox, P. M., Betts, R. A., Bunton, C. B., Essery, R. L. H., Rowntree, P. R., and Smith, J.: The impact of new land surface physics on the GCM simulation of climate and climate sensitivity, Clim. Dynam., 15, 183-203, doi:10.1007/s003820050276, 1999.

Cunningham, S. A., Kanzow, T., Rayner, D., Baringer, M. O., Johns, W. E., Marotzke, J., Longworth, H. R., Grant, E. M., Hirschi, J. J.-M., Beal, L. M., Meinen, C. S., and Bryden, H. L.: Temporal Variability of the Atlantic Meridional Overturning Circulation at $26.5^{\circ}$ N, Science, 317, 935-938, doi:10.1126/science.1141304, 2007.

Decima, A. and Wezel, F.: Late Miocene evaporites of the Central Sicilian Basin, DSDP Leg 13 Init Rep., 13, 1234-1240, 1973.
Demicco, R. V., Lowenstein, T. K., and Hardie, L. A.: Atmospheric pCO2 since $60 \mathrm{Ma}$ from records of seawater $\mathrm{pH}$, calcium, and primary carbonate mineralogy, Geology, 31, 793-796, doi:10.1130/G19727.1, 2003.

Dowsett, H. J. and Cronin, T. M.: High eustatic sea level during the middle Pliocene:Evidence from the southeastern U.S. Atlantic Coastal Plain, Geology, 18, 435-438, doi:10.1130/00917613(1990)018<0435:HESLDT>2.3.CO;2, 1990.

Dowsett, H. J., Barron, J. A., Poore, R. Z., Thompson, R. S., Cronin, T. M., Ishman, S. E., and Willard, D. A.: Middle Pliocene Paleoenvironmental Reconstruction: PRISM2, USGS Open File Rep., 99-535, available at: http://pubs.usgs.gov/of/ 1999/of99-535/ (last access: 20 May 2013), 1999.

Duggen, S., Hoernle, K., van den Bogaard, P., Rüpke, L., and Phipps Morgan, J.: Deep roots of the Messinian salinity crisis, Nature, 422, 602-606, doi:10.1038/nature01553, 2003.

Dutay, J.-C., Sepulchre, P., Arsouze, T., and Jaramillo, C.: Modeling $\mathrm{Nd}$ oceanic cycle in present and past climate, with a focus on the closure of the Panama isthmus during the Miocene, oral presentation at the 22nd Goldschmidt Geochemistry Conference, Montreal (Canada), 24-29 June, 2012.

Dvorkin, Y., Lensky, N. G., Lyakhovsky, V., and Gavrieli, I.: Description and benchmarking of the 1D multi-component chemistry-based model for the Dead Sea (1D-DS-POM), Ministry of National Infrastructures, Geological Survey of Israel, Jerusalem, 2007.

Edwards, J. M. and Slingo, A.: Studies with a flexible new radiation code. I: Choosing a configuration for a largescale model, Q. J. Roy. Meteorol. Soc., 122, 689-719, doi:10.1002/qj.49712253107, 1996.

Flecker, R. and Ellam, R. M.: Identifying Late Miocene episodes of connection and isolation in the Mediterranean-Paratethyan realm using Sr isotopes, Sediment. Geol., 188-189, 189-203, doi:10.1016/j.sedgeo.2006.03.005, 2006.

Flecker, R., de Villiers, S., and Ellam, R.: Modelling the effect of evaporation on the salinity-87 $\mathrm{Sr} / 86 \mathrm{Sr}$ relationship in modern and ancient marginal-marine systems: the Mediterranean Messinian Salinity Crisis, Earth Planet. Sci. Lett., 203, 221-233, doi:10.1016/S0012-821X(02)00848-8, 2002.

Fofonoff, N. P.: The Physical properties of seawater, in The Sea, Vol. 1, edited by: Hill, M. N., 3-30, Interscience, New York, 1962.

Fofonoff, N. P. and Millard, R. C.: Algorithms for computation of fundamental properties of seawater, Working Paper, UNESCO, available at: https://darchive.mblwhoilibrary.org/handle/ 1912/2470 (last access: 13 May 2013), 1983.

Fortuin, A. R. and Krijgsman, W.: The Messinian of the Nijar Basin (SE Spain): sedimentation, depositional environments and paleogeographic evolution, Sediment. Geol., 160, 213-242, doi:10.1016/S0037-0738(02)00377-9, 2003.

Garcia-Castellanos, D. and Villaseñor, A.: Messinian salinity crisis regulated by competing tectonics and erosion at the Gibraltar arc, Nature, 480, 359-363, doi:10.1038/nature10651, 2011.

García-Lafuente, J., Sánchez-Román, A., Naranjo, C., and SánchezGarrido, J. C.: The very first transformation of the Mediterranean outflow in the Strait of Gibraltar, J. Geophys. Res., 116, C07010, doi:201110.1029/2011JC006967, 2011. 
Gent, P. R. and Mcwilliams, J. C.: Isopycnal Mixing in Ocean Circulation Models, J. Phys. Oceanogr., 20, 150-155, doi:10.1175/1520-0485(1990)020<0150:IMIOCM>2.0.CO;2, 1990.

Gladstone, R., Flecker, R., Valdes, P., Lunt, D., and Markwick, P.: The Mediterranean hydrologic budget from a Late Miocene global climate simulation, Palaeogeogr. Palaeoclimatol. Palaeoecol., 251, 254-267, doi:10.1016/j.palaeo.2007.03.050, 2007.

Gordon, C., Cooper, C., Senior, C. A., Banks, H., Gregory, J. M., Johns, T. C., Mitchell, J. F. B., and Wood, R. A.: The simulation of SST, sea ice extents and ocean heat transports in a version of the Hadley Centre coupled model without flux adjustments, Clim. Dynam., 16, 147-168, doi:10.1007/s003820050010, 2000.

Gregory, D., Kershaw, R., and Inness, P. M.: Parametrization of momentum transport by convection. II: Tests in single-column and general circulation models, Q. J. Roy. Meteorol. Soc., 123, 11531183, doi:10.1002/qj.49712354103, 1997.

Griffies, S. M., Böning, C., Bryan, F. O., Chassignet, E. P., Gerdes, R., Hasumi, H., Hirst, A., Treguier, A.-M., and Webb, D.: Developments in ocean climate modelling, Ocean Model., 2, 123-192, doi:10.1016/S1463-5003(00)00014-7, 2000.

Griffin, D. L.: The late Miocene climate of northeastern Africa: unravelling the signals in the sedimentary succession, J. Geol. Soc., 156, 817-826, doi:10.1144/gsjgs.156.4.0817, 1999.

Haywood, A. M., Dowsett, H. J., Otto-Bliesner, B., Chandler, M. A., Dolan, A. M., Hill, D. J., Lunt, D. J., Robinson, M. M., Rosenbloom, N., Salzmann, U., and Sohl, L. E.: Pliocene Model Intercomparison Project (PlioMIP): experimental design and boundary conditions (Experiment 1), Geosci. Model Dev., 3, 227-242, doi:10.5194/gmd-3-227-2010, 2010.

Haywood, A. M., Ridgwell, A., Lunt, D. J., Hill, D. J., Pound, M. J., Dowsett, H. J., Dolan, A. M., Francis, J. E., and Williams, M.: Are there pre-Quaternary geological analogues for a future greenhouse warming?, Philos. Trans. R. Soc. Math. Phys. Eng. Sci., 369, 933-956, doi:10.1098/rsta.2010.0317, 2011.

Haywood, A. M. and Valdes, P. J.: Modelling Pliocene warmth: contribution of atmosphere, oceans and cryosphere, Earth Planet. Sci. Lett., 218, 363-377, doi:10.1016/S0012-821X(03)00685-X, 2004.

Herold, N., Huber, M., Müller, R. D., and Seton, M.: Modeling the Miocene climatic optimum: Ocean circulation, Paleoceanography, 27, PA1209, doi:10.1029/2010PA002041, 2012.

Hibler, W. D.: A Dynamic Thermodynamic Sea Ice Model, J. Phys. Oceanogr., 9, 815-846, doi:10.1175/15200485(1979)009<0815:ADTSIM>2.0.CO;2, 1979.

Hilgen, F., Bissoli, L., Iaccarino, S., Krijgsman, W., Meijer, R., Negri, A., and Villa, G.: Integrated stratigraphy and astrochronology of the Messinian GSSP at Oued Akrech (Atlantic Morocco), Earth Planet. Sci. Lett., 182, 237-251, doi:10.1016/S0012821X(00)00247-8, 2000.

Hodell, D. A., Benson, R. H., Kent, D. V., Boersma, A., and Bied, K. R.-E.: Magnetostratigraphic, biostratigraphic, and stable isotope stratigraphy of an Upper Miocene drill core from the Salé Briqueterie (northwestern Morocco): A high-resolution chronology for the Messinian stage, Paleoceanography, 9, 835-855, doi:10.1029/94PA01838, 1994.
Hsu, K. J., Montadert, L., Bernoulli, D., Cita, M. B., Erickson, A., Garrison, R. E., Kidd, R. B., Mèlierés, F., Müller, C., and Wright, R.: History of the Mediterranean salinity crisis, Nature, 267, 399-403, doi:10.1038/267399a0, 1977.

Hsu, K. J., Ryan, W. B. F., and Cita, M. B.: Late Miocene Desiccation of the Mediterranean, Nature, 242, 240-244, doi:10.1038/242240a0, 1973.

Hüsing, S. K., Oms, O., Agustí, J., Garcés, M., Kouwenhoven, T. J., Krijgsman, W., and Zachariasse, W.-J.: On the late Miocene closure of the Mediterranean-Atlantic gateway through the Guadix basin (southern Spain), Palaeogeogr. Palaeoclimatol. Palaeoecol., 291, 167-179, doi:10.1016/j.palaeo.2010.02.005, 2010.

Ivanovic, R. F., Flecker, R., Gutjahr, M., and Valdes, P. J.: First Nd isotope record of Mediterranean-Atlantic water exchange through the Moroccan Rifian Corridor during the Messinian Salinity Crisis, Earth Planet. Sci. Lett., 368, 163-174, doi:10.1016/j.epsl.2013.03.010, 2013a.

Ivanovic, R. F., Valdes, P. J., Flecker, R., Gregoire, L. J., and Gutjahr, M.: The parameterisation of Mediterranean-Atlantic water exchange in the Hadley Centre model HadCM3, and its effect on modelled North Atlantic climate, Ocean Model., 62, 11-16, doi:10.1016/j.ocemod.2012.11.002, 2013b.

Ivanovic, R. F., Valdes, P. J., Gregoire, L., Flecker, R., and Gutjahr, M.: Sensitivity of modern climate to the presence, strength and salinity of Mediterranean-Atlantic exchange in a global general circulation model, Clim. Dynam., 42, 859-877, doi:10.1007/s00382-013-1680-5, 2014.

Johns, T. C., Carnell, R. E., Crossley, J. F., Gregory, J. M., Mitchell, J. F. B., Senior, C. A., Tett, S. F. B., and Wood, R. A.: The second Hadley Centre coupled ocean-atmosphere GCM: model description, spinup and validation, Clim. Dynam., 13, 103-134, doi:10.1007/s003820050155, 1997.

Kageyama, M., Merkel, U., Otto-Bliesner, B., Prange, M., AbeOuchi, A., Lohmann, G., Roche, D. M., Singarayer, J., Swingedouw, D., and Zhang, X.: Climatic impacts of fresh water hosing under Last Glacial Maximum conditions: a multi-model study, Clim. Past, 9, 935-953, doi:10.5194/cp-9-935-2013, 2013.

Kahana, R.: Modelling the interactions between the Mediterranean and the Global Thermohaline Circulations, PhD thesis, University of East Anglia, Norwich, UK, 2005.

Krijgsman, W.: Astrochronology for the Messinian Sorbas basin (SE Spain) and orbital (precessional) forcing for evaporite cyclicity, Sediment. Geol., 140(1-2), 43-60, doi:10.1016/S00370738(00)00171-8, 2001.

Krijgsman, W., Gaboardi, S., Hilgen, F. j., Iaccarino, S., Kaenel, E. de, and Laan, E. van der: Revised astrochronology for the Ain el Beida section (Atlantic Morocco): No glacio-eustatic control for the onset of the Messinian Salinity Crisis, Stratigraphy, 1, 87101, 2004.

Krijgsman, W., Hilgen, F. J., Raffi, I., Sierro, F. J., and Wilson, D. S.: Chronology, causes and progression of the Messinian salinity crisis, Nature, 400, 652-655, doi:10.1038/23231, 1999a.

Krijgsman, W., Langereis, C. G., Zachariasse, W. J., Boccaletti, M., Moratti, G., Gelati, R., Iaccarino, S. M., Papani, G., and Villa, G.: Late Neogene evolution of the Taza-Guercif Basin (Rifian Corridor, Morocco) and implications for the Messinian salinity crisis, Mar. Geol., 153, 147-160, doi:10.1016/S0025-3227(98)00084X, 1999b. 
Krijgsman, W. and Meijer, P. T.: Depositional environments of the Mediterranean "Lower Evaporites" of the Messinian salinity crisis: Constraints from quantitative analyses, Mar. Geol., 253, 7381, doi:10.1016/j.margeo.2008.04.010, 2008.

Lofi, J., Déverchère, J., Gaullier, V., Gillet, H., Gorini, C., Guennoc, P., Loncke, L., Maillard, A., Sage, F., and Thinon, I.: Seismic Atlas of the "Messinian Salinity Crisis" Markers in the Mediterranean and Black Seas, Commission for the Geological Map of the World, Paris, France, 2011.

Lugli, S., Manzi, V., Roveri, M., and Charlotte, S. B.: The Primary Lower Gypsum in the Mediterranean: A new facies interpretation for the first stage of the Messinian salinity crisis, Palaeogeogr. Palaeoclimatol. Palaeoecol., 297, 83-99, doi:10.1016/j.palaeo.2010.07.017, 2010.

Lunt, D. J., Valdes, P. J., Haywood, A., and Rutt, I. C.: Closure of the Panama Seaway during the Pliocene: implications for climate and Northern Hemisphere glaciation, Clim. Dynam., 30, 1-18, doi:10.1007/s00382-007-0265-6, 2008.

Markwick, P. J.: The Palaeogeographic and Palaeoclimatic Significance of Climate Proxies for Data-Model Comparisons, in: Deep-Time Perspectives on Climate Change: Marrying the Signal from Computer Models and Biological Proxies, edited by: Williams, M., Haywood, A. M., Gregory, F. J., and Schmidt, D. N., 251-312, The Micropalaeontological Society Special Publications, The Geological Society, London, 2007.

Martín, J. M., Braga, J. C., Aguirre, J., and Puga-Bernabéu, Á.: History and evolution of the North-Betic Strait (Prebetic Zone, Betic Cordillera): A narrow, early Tortonian, tidal-dominated, Atlantic-Mediterranean marine passage, Sediment. Geol., 216, 80-90, doi:10.1016/j.sedgeo.2009.01.005, 2009.

Meijer, P. T.: A box model of the blocked-outflow scenario for the Messinian Salinity Crisis, Earth Planet. Sci. Lett., 248, 486-494, doi:10.1016/j.epsl.2006.06.013, 2006.

Meijer, P. T.: Hydraulic theory of sea straits applied to the onset of the Messinian Salinity Crisis, Mar. Geol., 326-328, 131-139, doi:10.1016/j.margeo.2012.09.001, 2012.

Meijer, P. T. and Krijgsman, W.: A quantitative analysis of the desiccation and re-filling of the Mediterranean during the Messinian Salinity Crisis, Earth Planet. Sci. Lett., 240, 510-520, doi:10.1016/j.eps1.2005.09.029, 2005.

Molnar, P.: Closing of the Central American Seaway and the Ice Age: A critical review, Paleoceanography, 23, PA2201, doi:10.1029/2007PA001574, 2008.

Muiños, S. B., Frank, M., Maden, C., Hein, J. R., Flierdt, T. van de, Lebreiro, S. M., Gaspar, L., Monteiro, J. H., and Halliday, A. N.: New constraints on the $\mathrm{Pb}$ and $\mathrm{Nd}$ isotopic evolution of NE Atlantic water masses, Geochem. Geophys. Geosystems, 9, Q02007, doi:200810.1029/2007GC001766, 2008.

Murdock, T. Q., Weaver, A. J., and Fanning, A. F.: Paleoclimatic response of the closing of the Isthmus of Panama in a coupled ocean-atmosphere model, Geophys. Res. Lett., 24, 253-256, doi:10.1029/96GL03950, 1997.

Murphy, L. N., Kirk-Davidoff, D. B., Mahowald, N., and OttoBliesner, B. L.: A numerical study of the climate response to lowered Mediterranean Sea level during the Messinian Salinity Crisis, Palaeogeogr. Palaeoclimatol. Palaeoecol., 279, 41-59, doi:10.1016/j.palaeo.2009.04.016, 2009.
Osborne, A. H., Frank, M., and Tiedemann, R.: The Pliocene closure of the Central American Seaway: reconstructing surface, intermediate- and deep-water connections, oral presentation at the 22nd Goldschmidt Geochemistry Conference, Montreal (Canada), 24-29 June, 2012.

Pagani, M., Freeman, K. H., and Arthur, M. A.: Late Miocene Atmospheric $\mathrm{CO}_{2}$ Concentrations and the Expansion of C4 Grasses, Science, 285, 876-879, doi:10.1126/science.285.5429.876, 1999.

Penaud, A., Eynaud, F., Sánchez-Goñi, M., Malaizé, B., Turon, J. L., and Rossignol, L.: Contrasting sea-surface responses between the western Mediterranean Sea and eastern subtropical latitudes of the North Atlantic during abrupt climatic events of MIS 3, Mar. Micropaleontol., 80, 1-17, doi:10.1016/j.marmicro.2011.03.002, 2011.

Pope, V. D., Gallani, M. L., Rowntree, P. R., and Stratton, R. A.: The impact of new physical parametrizations in the Hadley Centre climate model: HadAM3, Clim. Dynam., 16, 123-146, doi:10.1007/s003820050009, 2000.

Pound, M. J., Haywood, A. M., Salzmann, U., and Riding, J. B.: Global vegetation dynamics and latitudinal temperature gradients during the Mid to Late Miocene (15.97-5.33 Ma), Earth-Sci. Rev., 112, 1-22, doi:10.1016/j.earscirev.2012.02.005, 2012.

Prange, M. and Schulz, M.: A coastal upwelling seesaw in the Atlantic Ocean as a result of the closure of the Central American Seaway, Geophys. Res. Lett., 31, L17207, doi:10.1029/2004GL020073, 2004.

Rahmstorf, S.: Influence of Mediterranean Outflow on climate, Eos, 79, 281-282, doi:10.1029/98EO00208, 1998.

Robinson, M. M., Valdes, P. J., Haywood, A. M., Dowsett, H. J., Hill, D. J., and Jones, S. M.: Bathymetric controls on Pliocene North Atlantic and Arctic sea surface temperature and deepwater production, Palaeogeogr. Palaeoclimatol. Palaeoecol., 309, 9297, doi:10.1016/j.palaeo.2011.01.004, 2011.

Rogerson, M., Colmenero-Hidalgo, E., Levine, R. C., Rohling, E. J., Voelker, A. H. L., Bigg, G. R., Schönfeld, J., Cacho, I., Sierro, F. J., Löwemark, L., Reguera, M. I., Abreu, L. de, and Garrick, K.: Enhanced Mediterranean-Atlantic exchange during Atlantic freshening phases, Geochem. Geophys. Geosystems, 11, Q08013, doi:10.1029/2009GC002931, 2010.

Rogerson, M., Rohling, E. J., Bigg, G. R., and Ramirez, J.: Paleoceanography of the Atlantic-Mediterranean exchange: Overview and first quantitative assessment of climatic forcing, Rev. Geophys., 50, RG2003, doi:201210.1029/2011RG000376, 2012.

Rogerson, M., Rohling, E. J., and Weaver, P. P. E.: Promotion of meridional overturning by Mediterranean-derived salt during the last deglaciation, Paleoceanography, 21, PA4101, doi:10.1029/2006PA001306, 2006.

Roveri, M., Bergamasco, A., Carniel, S., Gennari, R., Lugli, S., and Manzi, V.: The origin of Messinian canyons in the Mediterranean basin: towards an alternative model for the Messinian Salinity Crisis, oral presentation at the joint RCMNS-RCANS Interim Colloquium, Salamanca, Spain, 21-23 September, 2011.

Roveri, M., Lugli, S., Manzi, V., and Schreiber, B. C.: The Messinian Sicilian stratigraphy revisited: new insights for the Messinian salinity crisis, Terra Nova, 20, 483-488, doi:10.1111/j.1365-3121.2008.00842.x, 2008. 
Ryan, W. B. F. and Cita, M. B.: The nature and distribution of Messinian erosional surfaces - Indicators of a several-kilometerdeep Mediterranean in the Miocene, Mar. Geol., 27, 193-230, doi:10.1016/0025-3227(78)90032-4, 1978.

Ryan, W. B. F., Hsu, K. J., Cita, M. B., Dumitrica, P., Lort, J. M., Maync, W., Nestero, W. D., Pautot, G., Stradner, H., and Wezel, F. C.: Initial Reports of the Deep Sea Drilling Project, 13, US Government Printing Office, available at: http://deepseadrilling. org/13/dsdp_toc.htm (last access: 19 June 2012), 1973.

Santisteban, C. and Taberner, C.: Shallow marine and continental conglomerates derived from coral reef complexes after desiccation of a deep marine basin: the Tortonian-Messinian deposits of the Fortuna Basin, SE Spain, J. Geol. Soc., 140, 401-411, doi:10.1144/gsjgs.140.3.0401, 1983.

Schneck, R., Micheels, A., and Mosbrugger, V.: Climate modelling sensitivity experiments for the Messinian Salinity Crisis, Palaeogeogr. Palaeoclimatol. Palaeoecol., 286, 149-163, doi:10.1016/j.palaeo.2009.12.011, 2010.

Schneider, B. and Schmittner, A.: Simulating the impact of the Panamanian seaway closure on ocean circulation, marine productivity and nutrient cycling, Earth Planet. Sci. Lett., 246, 367-380, doi:16/j.epsl.2006.04.028, 2006.

Simmons, A. J. and Burridge, D. M.: An Energy and AngularMomentum Conserving Vertical Finite-Difference Scheme and Hybrid Vertical Coordinates, Mon. Weather Rev., 109, 758-766, doi:10.1175/1520-0493(1981)109<0758:AEAAMC>2.0.CO;2, 1981.

Steph, S., Tiedemann, R., Prange, M., Groeneveld, J., Schulz, M., Timmermann, A., Nürnberg, D., Rühlemann, C., Saukel, C., and Haug, G. H.: Early Pliocene increase in thermohaline overturning: A precondition for the development of the modern equatorial Pacific cold tongue, Paleoceanography, 25, PA2202, doi:10.1029/2008PA001645, 2010.

Stouffer, R. J., Yin, J., Gregory, J. M., Dixon, K. W., Spelman, M. J., Hurlin, W., Weaver, A. J., Eby, M., Flato, G. M., Hasumi, H., Hu, A., Jungclaus, J. H., Kamenkovich, I. V., Levermann, A., Montoya, M., Murakami, S., Nawrath, S., Oka, A., Peltier, W. R., Robitaille, D. Y., Sokolov, A., Vettoretti, G., and Weber, S. L.: Investigating the Causes of the Response of the Thermohaline Circulation to Past and Future Climate Changes, J. Climate, 19, 1365-1387, doi:10.1175/JCLI3689.1, 2006.

Thierstein, H. R. and Berger, W. H.: Injection events in ocean history, Nature, 276, 461-466, doi:10.1038/276461a0, 1978.
Topper, R. P. M., Flecker, R., Meijer, P. T., and Wortel, M. J. R.: A box model of the Late Miocene Mediterranean Sea: Implications from combined $87 \mathrm{Sr} / 86 \mathrm{Sr}$ and salinity data, Paleoceanography, 26, PA3223, doi:10.1029/2010PA002063, 2011.

Van Assen, E., Kuiper, K. F., Barhoun, N., Krijgsman, W., and Sierro, F. J.: Messinian astrochronology of the Melilla Basin: Stepwise restriction of the Mediterranean-Atlantic connection through Morocco, Palaeogeogr. Palaeoclimatol. Palaeoecol., 238, 15-31, doi:10.1016/j.palaeo.2006.03.014, 2006.

Visbeck, M., Marshall, J., Haine, T., and Spall, M.: Specification of Eddy Transfer Coefficients in Coarse-Resolution Ocean Circulation Models*, J. Phys. Oceanogr., 27, 381-402, doi:10.1175/1520-0485(1997)027<0381:SOETCI>2.0.CO;2, 1997.

Voelker, A. H. L., Lebreiro, S., Schonfeld, J., Cacho, I., Erlenkeuser, H., and Abrantes, F.: Mediterranean outflow strengthening during northern hemisphere coolings: A salt source for the glacial Atlantic?, Earth Planet. Sci. Lett., 245, 39-55, doi:10.1016/j.eps1.2006.03.014, 2006.

Van de Wal, R. S. W., de Boer, B., Lourens, L. J., Köhler, P., and Bintanja, R.: Reconstruction of a continuous high-resolution $\mathrm{CO}_{2}$ record over the past 20 million years, Clim Past, 7, 14591469, doi:10.5194/cp-7-1459-2011, 2011.

Van der Laan, E., Snel, E., Kaenel, E. de, Hilgen, F. J., and Krijgsman, W.: No major deglaciation across the Miocene-Pliocene boundary: Integrated stratigraphy and astronomical tuning of the Loulja sections (Bou Regreg area, NW Morocco), Paleoceanography, 21, PA3011, doi:10.1029/2005PA001193, 2006.

Wu, W., Danabasoglu, G., and Large, W. G.: On the effects of parameterized Mediterranean overflow on North Atlantic ocean circulation and climate, Ocean Model., 19, 31-52, doi:10.1016/j.ocemod.2007.06.003, 2007.

Zhang, R. and Delworth, T. L.: Simulated Tropical Response to a Substantial Weakening of the Atlantic Thermohaline Circulation, J. Climate, 18, 1853-1860, doi:10.1175/JCLI3460.1, 2005.

Zhang, X., Prange, M., Steph, S., Butzin, M., Krebs, U., Lunt, D. J., Nisancioglu, K. H., Park, W., Schmittner, A., Schneider, B., and Schulz, M.: Changes in equatorial Pacific thermocline depth in response to Panamanian seaway closure: Insights from a multi-model study, Earth Planet. Sci. Lett., 317-318, 76-84, doi:10.1016/j.eps1.2011.11.028, 2012. 